\section{To: (Receiving Organization) \\ Distribution}

5. Proj./Prog./Dept./Div.:

Spent Nuclear Fuel Project

8. Originator Remarks:

For approval and release.

11. Receiver Remarks: 11A. Design Beseline Document? [] Yes [X] Mo
3. From: (Originating Organization) Sludge Treatment Project

6. Design Authority/ Desion Agent/Cog. Engr.:

A. G. Westra Numatec Hanford Corporation

\section{Related EDT No.: NA \\ 7. Purchase Order No.: NA}

9. Equip./Component No.: NA

10. Systen/Blog./facility: NA

12. Major Assm. Owg. No.: NA

13. Permit/Permit Application No.: NA

14. Requíred Response Date: NA

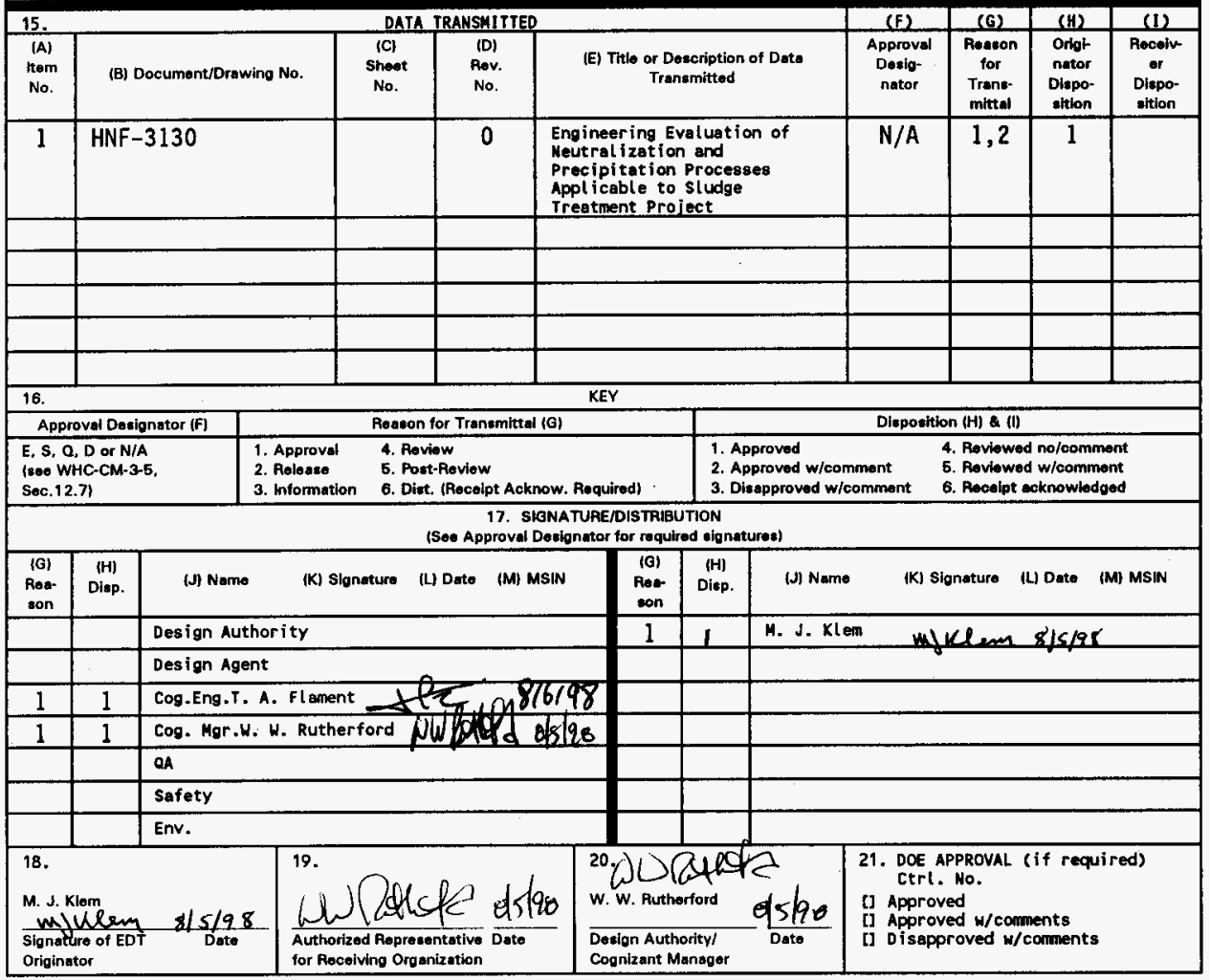




\title{
Engineering Evaluation of Neutralization and Precipitation Processes Applicable to Sludge Treatment Project
}

\author{
M. J. Klem
}

COGEMA Engineering Corporation

Richland, WA 99352

U.S. Department of Energy Contract DE-AC06-96RL13200

EDT/ECN: 625260

UC: 2000

Org Code: 8C700

B\&R Code: EW7040000

Charge Code: LD451 HANA2600

Total Pages: 34

Key Words: K Basin Sludge, Neutralization, TWRS

Abstract: This report presents an engineering evaluation of the neutralization process applicable to treatment of $K$ Basin sludge. The neutralized dissolver solution slurry will be transferred to the TWRS waste tanks for storage. The results of this evaluation show that the neutralized dissolver solution meets TWRS acceptance criteria and batch mixer tanks are recommended for the neutralization process.

TRADEMARK DISCLAIMER. Reference herein to any specific commercial product, process, or service by trade name, trademark, manufacturer, or otherwise, does not necessarly constitute or imply its endorsement, recommendation, or favoring by the United States Government or any agency thereof or its contractors or subcontractors.

Printed in the United States of America. To obtain copies of this document, contact: Document Control Services, P.O. Box 950, Mailstop H6-08, Richland WA 99352, Phone (509) 372-2420; Fax (509) 376-4989.

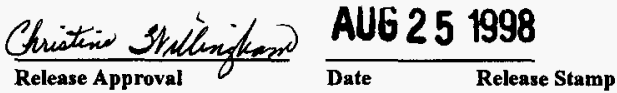

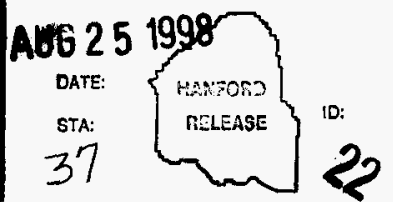


Table of Contents

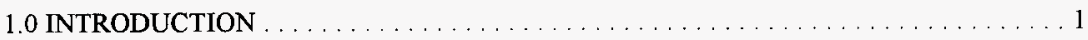

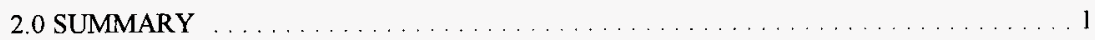

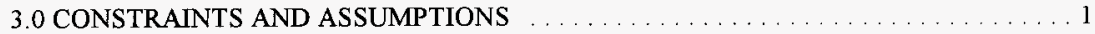

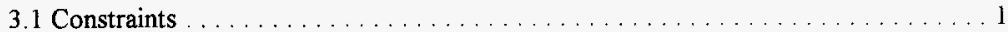

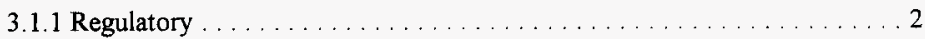

3.1.2 Tank Farm Waste Acceptance Criteria . . . . . . . . . . . . . . 2

3.1.3 Nuclear and Chemical Safety Requirements ............... 4

3.2 Assumptions . ............................... 4

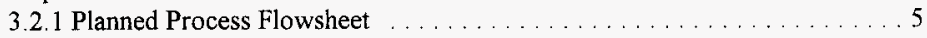

4.0 REVIEW OF NEUTRALIZATION AND PRECIPITATION EXPERIENCE $\ldots \ldots \ldots 6$

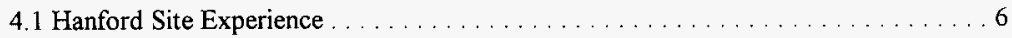

4.1 .1 Neutralization Methods ........................ 6

4.1.2 Particle Size of Neutralized Hanford Site Waste . . . . . . . . . . . 7

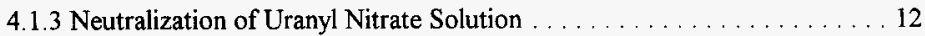

4.2 Other DOE Site Experience . . . . . . . . . . . . . . . . . . . . . 13

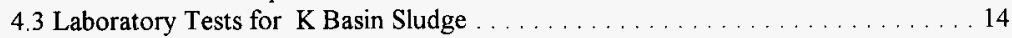

4.4 Other World Wide Experience .......................... 16

5.0 DESCRIPTION OF NEUTRALIZATION PROCESS TECHNOLOGIES $\ldots \ldots \ldots \ldots 17$

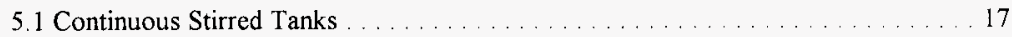

5.2 Static Mixers . . . . . . . . . . . . . . . . . . . . . . . . . . 17

5.3 Batch Mixer Tanks . . . . . . . . . . . . . . . . . . . . . . . . 20

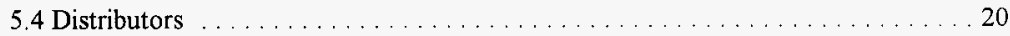

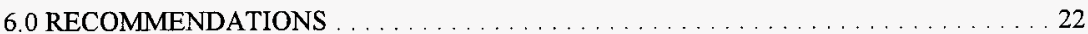

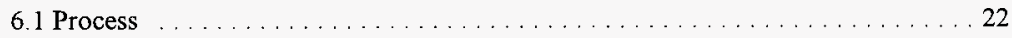

6.1 .1 Neutralization Method ......................... 22

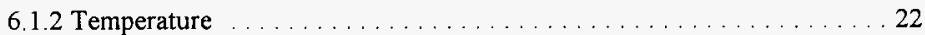

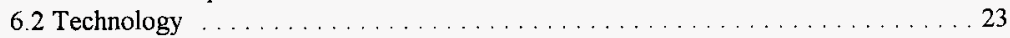

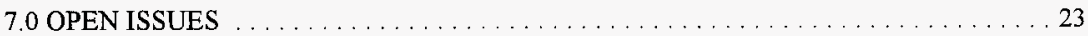

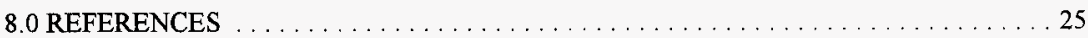

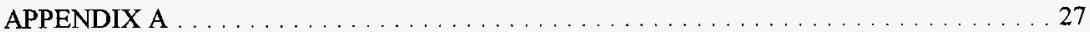




\section{TABLES}

3-1 Tank Farm Waste Acceptance Criteria . . . . . . . . . . . . . . . . . 3

3-2 Key Radionuclides and Other Constituents in Feed Stream to Neutralization . . . . . . . 6

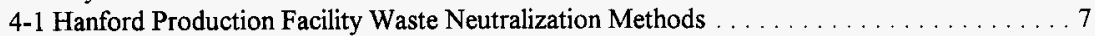

4-2 Purex Neutralization Tank Agitators . . . . . . . . . . . . . . . . . . 9

4-3 Particle Sizes in Neutralized and Simulated Zirflex Cladding Waste at Purex . . . . . . . 9

4-4 Particle Size in Direct Strike Neutralized and Simulated Redox Waste Cladding Waste . . 10

4-5 Size of Residual Particles in Supernate from Settling Tests of Simulated Direct Neutralized

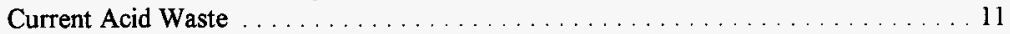

4-6 Particle Sizes Analysis of Simulated Neutralized Current Acid Waste Ripening . . . . . . 11

4-7 Particle Sizes in Simulated Reverse Neutralized Plutonium Finishing Plant Waste . . . . . 12

4-8 Particle Sizes in Simulated Direct Neutralized Savannah River Site Waste . . . . . . . . . 14

4-7 Particle Size Distributions of Precipitates from Direct Strike Alkaline Treatment of Simulated

Dissolver Solutions at $0.01 \mathrm{M}$ Excess $\mathrm{NaOH} \ldots \ldots \ldots \ldots \ldots \ldots \ldots \ldots$

\section{FIGURES}

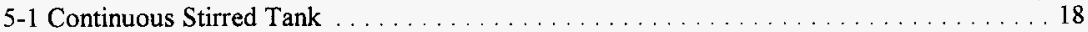

5-2A Two Port and Three Port Vortex Mixers . . . . . . . . . . . . . . . . . . . . 19

5-2B A Single Vortex Cell Mixing Device . . . . . . . . . . . . . . . . . . . . . 19

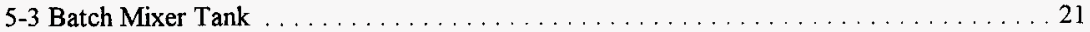




\section{LIST OF TERMS}

$\begin{array}{ll}\text { CAW } & \text { Current Acid Waste } \\ \text { DOE } & \text { Department of Energy } \\ \text { DST } & \text { Double-Shell Tank } \\ \text { ERDF } & \text { Environmental Restoration Disposal Facility } \\ \text { EDTA } & \text { Ethylenediaminetetraacetate } \\ \text { HAW } & \text { High Activity Waste } \\ \text { HM } & \text { Heavy Metal } \\ \text { LAW } & \text { Low Activity Waste } \\ \text { NCAW } & \text { Neutralized Current Acid Waste } \\ \text { PUREX } & \text { Plutonium Uranium Extraction } \\ \text { PFP } & \text { Plutonium Finishing Plant } \\ \text { REDOX } & \text { Reduction Oxidation } \\ \text { TWRS } & \text { Tank Waste Remediation Waste System } \\ \text { TRU } & \text { Transuranic } \\ \text { WHC } & \text { Westinghouse Hanford Company } \\ \text { ZAW } & \text { Zirflex Acid Waste }\end{array}$


HNF-3130, Rev 0

\subsection{INTRODUCTION}

Engineering evaluations have been performed to determine likely unit operations and methods required to support the removal, storage, treatment and disposal of solids/sludges present in the $\mathrm{K}$ Basins at the Hanford Site. This evaluation was initiated to select a neutralization process for dissolver product solution resulting from nitric acid treatment of about $50 \mathrm{~m}^{3}$ of Hanford Site K Basins sludge. Neutralization is required to meet Tank Waste Remediation Waste System (TWRS) acceptance criteria for storage of the waste in the double shell tanks. After neutralization, the supernate and precipitate will be transferred to the high level waste storage tanks in $200 \mathrm{E}$ Area. Non transuranic (TRU) solids residue will be transferred to the Environmental Restoration Disposal Facility (ERDF).

This report presents an overview of neutralization and precipitation methods previously used and tested. This report also recommends a neutralization process to be used as part of the $\mathrm{K}$ Basins Sludge Treatment Project and identifies additional operations requiring further evaluation.

\subsection{SUMMARY}

A batch mixer tank is recommended for the neutralization/precipitation system. This equipment system is simple and has been used at the Hanford Site for neutralization of several waste types for 50 years using a direct strike (addition of $\mathrm{NaOH}$ solution to tank of acid solution) or reverse strike (addition of acid solution to tank of $\mathrm{NaOH}$ solution) neutralization of acid waste. The reverse strike neutralization method is recommended for good coprecipitation of $\mathrm{Pu}$ and $\mathrm{Fe}$ and elimination of the gelatinous $\mathrm{Al}(\mathrm{OH})_{3}$ at $\mathrm{pH} 4$ to 5 by maintaining high alkaline conditions during the entire neutralization/precipitation process. Depending on the size of the tank, agitator speed and mixing characteristics of the alkaline slurry, a distributor may be used for addition of the dissolver product solution to the $\mathrm{NaOH}$ in the tank. The distributor would prevent temporary and localized unmixed solution.

Work needs to continue on resolution of uncertainties associated with cost, flexibility, schedule, environmental impact, operation, maintenance and safety of the proposed pretreatment process.

\subsection{CONSTRAINTS AND ASSUMPTIONS}

This section will describe the constraints and assumptions that define the framework for neutralization of the dissolver solution.

\subsection{Constraints}

Constraints are requirements that are imposed on the system by outside agencies and are beyond control of design, construction and operating requirements. 


\subsubsection{Regulatory}

The key constraints that will drive the K Basin Sludge Pretreatment process are the Code of Federal Regulations, the Washington Administrative Code, and Department of Energy (DOE) Orders. In addition there are guidelines and specifications that establish engineering requirements deemed necessary for safe design, construction and operation of the system. It is beyond the scope of this evaluation to identify constraints for the neutralization step and transfer of neutralized waste to the tank farms.

\subsubsection{Tank Farm Waste Acceptance Criteria}

The TWRS neutralization-specific waste acceptance criteria/requirements for the double-shell tanks are given in Table 3.1 (Carothers, et al. 1997, Mulkey 1997). Additional criteria from various sources are also included (e.g. Fe/Pu). 
Table 3-1 Tank Farm Waste Acceptance Criteria

\begin{tabular}{|c|c|}
\hline Parameter & Specification Limit \\
\hline \multicolumn{2}{|c|}{$1.0 \mathrm{M} \leq\left[\mathrm{NO}_{3}^{-}\right]$, Temperature $\leq 100^{\circ} \mathrm{C}$} \\
\hline$\left[\mathrm{OH}^{-}\right]^{(1)}$ & $0.010 \mathrm{M} \leq\left[\mathrm{OH}^{-}\right] \leq 5.0 \mathrm{M}$ \\
\hline$\left[\mathrm{NO}_{2}^{-}\right]$ & $0.011 \mathrm{M} \leq\left[\mathrm{NO}_{2}^{-}\right] \leq 0.5 \mathrm{M}$ \\
\hline$\left[\mathrm{NO}_{3}^{-}\right] /\left(\left[\mathrm{OH}^{-}\right]+\left[\mathrm{NO}_{2}^{-}\right]\right)$ & $<2.5$ \\
\hline \multicolumn{2}{|c|}{$1.0 \mathrm{M}<\left[\mathrm{NO}_{3}{ }^{-}\right] \leq 3.0 \mathrm{M}$, Temperature $\leq 100^{\circ} \mathrm{C}$} \\
\hline$\left[\mathrm{OH}^{-}\right]$ & $0.1\left(\left[\mathrm{NO}_{3}^{-}\right]\right) \leq\left[\mathrm{OH}^{-}\right]<10 \mathrm{M}$ \\
\hline$\left[\mathrm{OH}^{-}\right]+\left[\mathrm{NO}_{2}^{-}\right]$ & $\geq 0.4\left(\left[\mathrm{NO}_{3}^{-}\right]\right)$ \\
\hline \multicolumn{2}{|c|}{$\left[\mathrm{NO}_{3}\right]^{-}>\mathbf{3 . 0} \mathrm{M}$, Temperature $\leq 100^{\circ} \mathrm{C}$} \\
\hline$\left[\mathrm{OH}^{-}\right]$ & $0.3 \mathrm{M} \leq\left[\mathrm{OH}^{-}\right]<10 \mathrm{M}$ \\
\hline$\left[\mathrm{OH}^{-}\right]+\left[\mathrm{NO}_{2}^{-}\right]$ & $\geq 1.2 \mathrm{M}$ \\
\hline$\left[\mathrm{NO}_{3}^{-}\right]$ & $\leq 5.5 \mathrm{M}$ \\
\hline \multicolumn{2}{|c|}{ Other } \\
\hline${ }^{235} \mathrm{U}$ & $<0.84 \mathrm{wt} \%$ of total $\mathrm{U}$ \\
\hline Transuranics & $<100 \mathrm{nCi} / \mathrm{g}$ TRU supernate ${ }^{(2)}$ \\
\hline $\mathrm{Fe} / \mathrm{Pu}$ & $353 \mathrm{~g} \mathrm{~mole} / \mathrm{g}$ mole \\
\hline Particle size, fissile and poison material & $<50 \mu \mathrm{m}^{(3)}$ \\
\hline Particle size, non fissile material & $<177 \mu \mathrm{m}$ \\
\hline Specific gravity (comingled) & $<1.41$ \\
\hline Solids volume & $\begin{array}{l}\text { To prevent flammable gas retention, waste } \\
\text { tank liquid } \mathrm{SpG} \times \text { total solids depth (in.) } \\
<148.379 \mathrm{~m}^{3}(100,000 \text { gal) of solids can be } \\
\text { added to TK-AW-105 before exceeding this } \\
\text { requirement. }\end{array}$ \\
\hline
\end{tabular}

1) For solutions below $75^{\circ} \mathrm{C}$ the $\left[\mathrm{OH}^{-}\right]$maximum limit is $8.0 \mathrm{M}$.

2) If supernate exceeds TRU limit, DOE waiver may required.

3) Primary particle size, agglomeration to larger sizes acceptable. 
Parameters and control limits for criticality safety in double shell tanks (DST) are documented in WHC, 1995. K Basin sludge has a higher fissile material content than the waste in DSTs, therefore, a criticality feasibility analysis has been competed to define requirements necessary to assure criticality safety (Vail and Daling, 1997). The study concluded that the key control parameters are $\mathrm{pH}$, particle size, uranium 235 enrichment levels, and neutron absorbers. The study concludes that criticality issues for $\mathrm{K}$ Basin sludge are resolved by pretreatment of the sludge to ensure particle sizes less than 50 micron, addition of chemicals to ensure the waste is alkaline, and addition of either depleted uranium for isotopic dilution of the ${ }^{235} \mathrm{U}$ or addition of absorbers such as iron for Pu poison. Subcriticality, in non-criticality safe geometries is ensured by maintaining fissile material concentrations below minimum for which criticality is possible (e.g. batch size) or by a subcritical mass ratio of neutron absorbers to fissile material.

\subsubsection{Nuclear and Chemical Safety Requirements}

The following safety concerns have been identified for the adjustment and neutralization process:

Criticality - The operations in this process must provide an adequate margin of subcriticality to ensure criticality safety. Criticality control in the dissolution step is based on limits for the mass of fissile material in a batch of sludge. Therefore, criticality control for later processing steps, including the adjustment process, is established by the controls used to limit the batch mass in the dissolver provided multiple batching and fissile material buildup in equipment is prevented. The adjustment and neutralization process also includes addition of neutron absorber material (either depleted uranium and/or iron) for criticality control of the solution for transfer to the tank farms.

Confinement - Confinement of radioactive or other hazardous materials involved in the process requires containing the spread of this material to within identified and controlled boundaries preventing, if possible, or helping to minimize the spread to occupied areas, minimizing the releases in facility effluents during normal operations and anticipated occurrences and limiting the releases resulting from design basis accidents.

Reaction Control - Heat is generated during the neutralization process. The rate of heat generation must be controlled to ensure process control and prevent excessive temperatures or pressures to challenge to the containment boundary.

Flammable Gas - The concentration of hydrogen gas must be maintained below the flammable limit. Hydrogen gas can be generated as a result of radiolysis of the water.

\subsection{Assumptions}

Assumptions were made for areas where limited information is available and the required analysis has not been completed. The main assumptions used in this evaluation are described below. 
HNF-3130, Rev 0

\subsubsection{Planned Process Flowsheet}

The planned flowsheet for processing $\mathrm{K}$ Basin sludges includes resins separations, sludge dissolution, solid separation, and neutralization/precipitation as discussed in the system description (Westra 1998). The block diagram and stream data for the whole flowsheet are documented in Westra 1998. The data important to the neutralization process are given in Table 3-2 for nominal sludge from the K East and $\mathrm{K}$ West Basins. The detailed composition of the streams are provided in Appendix A.

After separation of ion exchange resins, the sludge will be processed in a dissolver where uranium, iron and other compounds will be dissolved in nitric acid. Resins and insolubles will be leached out with an acidic solution to remove residual amounts of TRU and washed to reduce adherent films of TRU containing water. Insolubles such as silica and graphitic materials will exist in solution as an undissolved species. These insoluble residues will be solidified/stabilized (e.g., grout) and sent to ERDF. The dissolver product and the different leaching solution used to treat the solid residue is treated with $\mathrm{NaOH}$ solution where metal ions are precipitated in accordance with tank farm criteria. The resulting slurry will be transferred to a DST in 200 East Area.

The solution in the neutralization feed tank will be agitated and sampled. The samples will be analyzed for $\mathrm{Pu}^{239,240}, \mathrm{Am}^{241}$, uranium isotopic, $\mathrm{Cs}^{137}, \mathrm{Sr}^{90}, \mathrm{H}^{+}, \mathrm{Fe}, \mathrm{Al}, \mathrm{Ca}, \mathrm{PCBs}$ and other components as required by the TWRS acceptance criteria. The results of the analysis and volume of solution in the tank will be used to determine how much depleted uranium and iron will be added as neutron absorbers, $\mathrm{NaOH}$ for neutralization and $\mathrm{NaNO}_{2}$ for corrosion control to achieve tank waste acceptance. Both absorbers will be added since laboratory studies have shown that after co-precipitation of $\mathrm{Pu}, \mathrm{Am}$ and $\mathrm{U}$ under simulated waste tank conditions, $\mathrm{Pu}$ can selectively dissolve if it is exposed to carbonate bearing solution and Am can dissolve if exposed to the solution containing the sodium salt of ethylenediaminetetraacetate (EDTA) during waste retrieval operations. 
HNF-3130, Rev 0

Table 3-2 Key Radionuclides and Other Constituents in Feed Stream to Neutralization

\begin{tabular}{|c|c|c|}
\hline \multirow[t]{2}{*}{ Constituent } & \multicolumn{2}{|c|}{ Batch Case $^{(1)}$} \\
\hline & KE 1 & KW 2 \\
\hline $\mathrm{Al}, \mathrm{M}$ & 0.056 & 0.0050 \\
\hline $\mathrm{Fe}, \mathrm{M}$ & 0.14 & 0.85 \\
\hline $\mathrm{HNO}_{3}, \mathrm{M}$ & 4.3 & 3.4 \\
\hline $\mathrm{U}, \mathbf{M}$ & 0.018 & 0.13 \\
\hline $\mathrm{Pu} \mathrm{mCi/l}$ & 0.7 & 5.2 \\
\hline $\mathrm{Am} \mathrm{mCi} / 1$ & 0.89 & 4.3 \\
\hline $\mathrm{Cs}^{137} \mathrm{mCi} / \mathrm{l}$ & 11.3 & 168 \\
\hline
\end{tabular}

1) Nominal case is starting batch size of $160 \mathrm{~kg}$ sludge solids.

\subsection{REVIEW OF NEUTRALIZATION AND PRECIPITATION EXPERIENCE}

Information on production facility waste neutralization was compiled from technical manuals, laboratory tests on simulated waste and discussions with cognizant engineers and scientists. The neutralization information is summarized in the below sections for Hanford and offsite facilities.

\subsection{Hanford Site Experience}

\subsubsection{Neutralization Methods}

Table 4-1 identifies the waste neutralization methods used at the Hanford Site production facilities. A direct strike (sodium hydroxide addition to acid waste) or reverse strike (acid waste addition to sodium hydroxide) neutralization method was used depending on the waste type. Reverse strike neutralization was used at the Redox facility and the Plutonium Finishing Plant (PFP) because of the high concentration of aluminum nitrate salting agent in the waste and at the Purex facility for the zirflex cladding waste.

Zirconium clad fuel was processed at the Redox facility shortly before the facility was shut down. Process flowsheet information (Boldt 1966) and conversations with R. A. Watrous and A. L. Boldt on Redox operations did not identify the method used for neutralization of the zirflex cladding waste. It is assumed that the direct strike neutralization method used in laboratory waste neutralization tests (Schull and Herting, 1986) was the actual neutralization method used in the Redox process for zirflex cladding waste. 
HNF-3130, Rev 0

Table 4-1 Hanford Production Facility Waste Neutralization Methods

\begin{tabular}{|c|c|c|}
\hline Chemical Process & Direct Strike & Reverse Strike \\
\hline Bismuth Phosphate & $\mathrm{x}$ & metal solution waste \\
\hline $\begin{array}{c}\text { Reduction Oxidation } \\
\text { (REDOX) }\end{array}$ & zirflex cladding waste & zirflex cladding waste \\
\hline Uranium Recovery & $\mathrm{x}$ & $\mathrm{x}$ \\
\hline $\begin{array}{c}\text { Plutonium-Uranium } \\
\text { Extraction } \\
\text { (PUREX) }\end{array}$ & $\mathrm{CAW/ZAW} \mathrm{\text {stream } ^ { ( 1 ) }}$ & \\
\hline Waste Fractionization & $\mathrm{x}$ & \\
\hline $\begin{array}{c}\text { Plutonium } \\
\text { Reclamation/Conversion } \\
\text { (PFP) }\end{array}$ & $\begin{array}{c}\text { changed to reverse due to } \\
\mathrm{Al}(\mathrm{OH})_{3} \text { problem }\end{array}$ & \\
\hline
\end{tabular}

1) CAW is acronym for current acid waste. ZAW is acronym for zirflex acid waste - current acid waste from processing zirconium clad fuel elements.

The reverse strike neutralization for high aluminum nitrate - nitric acid metal waste was used because at $\mathrm{pH}$ of 4 or 5 the gelatinous precipitate $\left(\mathrm{Al}(\mathrm{OH})_{3}\right.$ or $\left.\mathrm{Al}_{2} \mathrm{O}_{3} \cdot 3 \mathrm{H}_{2} \mathrm{O}\right)$ becomes so heavy that agitation is difficult. As more caustic is added, the mass becomes less viscous and at $\mathrm{pH} 6$ or 7 , the precipitation is complete. The freshly precipitated hydroxide is readily soluble in excess $\mathrm{NaOH}$ as sodium aluminate. Dissolution of $\mathrm{Al}(\mathrm{OH})_{3}$ is slower or incomplete if a) the direct strike caustic is added too slowly with insufficient agitation, b) the precipitate is allowed to age for any extended time period (several hours) before dissolution in excess $\mathrm{NaOH}$, or c) if the temperature is allowed to go to $>50^{\circ} \mathrm{C}$ during neutralization (GE 1951). Conversation with J. S. Buckingham (40 years process chemistry support experience at Hanford laboratories) stated that $\mathrm{Al}(\mathrm{OH})_{3}$ solids from direct neutralization of 1-2 M Al solution will stop an agitator.

\subsubsection{Particle Size of Neutralized Hanford Site Waste}

A search was performed on Hanford neutralized waste to obtain particle size information on precipitates. Particle size information was obtained for several simulated wastes from the production facilities. These wastes included neutralized cladding waste, neutralized metal waste and neutralized high aluminum salt waste. Additional information was located on particle size of

retrieved waste from the single shell tanks for the strontium removal program in the 1970s. The particle size information for retrieved tank waste was not used in this study. 
Conversation with D. L. Herting ( 20 years process support experience at Hanford Site laboratories) identified that particle size tests were performed with simulated fuel element cladding waste and waste transfer line constriction is often the result of accumulation of needle type crystals. Particle size of non fissile material added to the waste tanks is limited to $<177 \mu \mathrm{m}$ by specification. Conversations with R. E. Vandercook ( 40 years chemical engineering experience at Hanford Site production facilities) and with J. S. Buckingham ( 40 years process chemistry support experience at Hanford Site laboratories) resulted in neither of them remembering any specific studies on particle size of solids from neutralization of the waste at the production facilities. Conversation revealed there was little interest in particle size of solids in the neutralized waste during the early production periods and results from available particle size analyzers were not reliable at the time.

Reverse strike neutralization of zirflex cladding waste at Purex was used to minimize the ammonia evolution rate to the off gas system, form slurriable solids $\mathrm{ZrO}_{2} \cdot 2 \mathrm{H}_{2} \mathrm{O}$ solids and increase the $\mathrm{pH}$ of the waste to meet tank waste acceptance criteria. The reverse strike coating waste-caustic reaction generated up to $50 \mathrm{vol} \%$ solids and required agitation for solids suspension in order to transfer the slurry to the waste tanks (RHO 1983). The transfer was followed by a 1900 liter water flush. Recent laboratory tests showed that direct strike neutralization of zirflex cladding waste generated about $40 \mathrm{vol} \%$ solids and reverse strike neutralization generated about $60 \mathrm{vol} \%$ solids (Schull and Herting 1986)

Information on the Purex neutralization tank agitators is listed in Table 4-2. Both tanks are 19,000 1 capacity. Specific information on Redox neutralization tank size and agitators could not be located. A 7.5 horse power or 5 horse power agitator was probably used with gear reducers and shaft speeds of $97 \mathrm{rpm}$ and $121 \mathrm{rpm}$ respectively. The 7.5 and 5.0 horsepower units have paddle-wheel propellers of $838 \mathrm{~mm}$ and $610 \mathrm{~mm}$ diameter respectively. Each propeller has 10 blades at a pitch of 15 degrees (GE 1951). 
HNF-3130, Rev 0

Table 4-2 Purex Neutralization Tank Agitators ${ }^{(1)}$

\begin{tabular}{|c|c|c|c|c|c|c|c|}
\hline \multirow{2}{*}{$\begin{array}{l}\text { Function } \\
\text { and Tank } \\
\text { Number }\end{array}$} & \multicolumn{2}{|c|}{ Motor } & \multicolumn{3}{|c|}{ Shaft } & \multicolumn{2}{|c|}{ Impeller } \\
\hline & $\begin{array}{l}\text { Speed } \\
\text { RPM }\end{array}$ & Horsepower & $\begin{array}{c}\text { Length } \\
\mathrm{mm}\end{array}$ & $\begin{array}{c}\text { Diameter } \\
\mathrm{mm}\end{array}$ & $\begin{array}{l}\text { Speed } \\
\text { RPM }\end{array}$ & Number & $\begin{array}{l}\text { Diameter } \\
\mathrm{mm}\end{array}$ \\
\hline $\begin{array}{l}\text { Coating } \\
\text { Waste } \\
\text { (E5) }\end{array}$ & 300 & 10 & 2590 & 51 & 300 & 1 & 355 \\
\hline $\begin{array}{l}\text { Current } \\
\text { Acid } \\
\text { Waste } \\
\text { (F16) }\end{array}$ & 600 & 15 & 2590 & 51 & 600 & 2 & 229 \\
\hline
\end{tabular}

1) Source of information is RHO 1983.

The neutralized waste particle size information is listed in Tables 4-3 to 4-7 for several Hanford Site waste types. Particle size was $\leq 10 \mu \mathrm{m}$ except for a few laboratory tests that combined simulated Redox aluminum waste and zirflex cladding waste. The large particles were generally cubic, square, and flat type and/or a needle type crystal. Small particles were symmetrical with a plane of symmetry (equant).

Table 4-3 Particle Sizes in Neutralized and Simulated Zirflex Cladding Waste at Purex ${ }^{(1)}$

\begin{tabular}{|c|c|c|c|c|}
\hline \multirow{2}{*}{ Method } & \multirow[t]{2}{*}{$\mathrm{pH}$} & \multicolumn{3}{|c|}{ Particle Description $\mu \mathrm{m}$} \\
\hline & & Equant & Cubic, Square, Flat & Needle \\
\hline Direct Strike ${ }^{(2)}$ & $10.6,11.0$ & $<2-10$ & - & - \\
\hline Reverse Strike ${ }^{(2)}$ & $10.7,10.8$ & $<2-5$ & - & - \\
\hline $\begin{array}{c}\text { Direct Strike } \\
(10 \% \text { excess } \mathrm{NaOH})^{(3)}\end{array}$ & $11.6,12.4$ & $<2-10$ & - & - \\
\hline $\begin{array}{c}\text { Reverse Strike } \\
(10 \% \text { excess } \mathrm{NaOH})^{(3)}\end{array}$ & $12.2,12.1$ & $<2-5$ & - & - \\
\hline
\end{tabular}

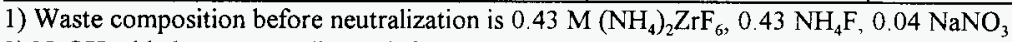

2) $\mathrm{NaOH}$ added to meet earlier tank farm waste acceptance criteria.

3) Excess $\mathrm{NaOH}$ added to meet current tank farm waste acceptance criteria for $\mathrm{pH}>12$. 
HNF-3130, Rev 0

Table 4-4 Particle Size in Direct Strike Neutralized and Simulated Redox Waste Cladding Waste ${ }^{(1)}$

\begin{tabular}{|l|c|c|c|c|}
\hline \multirow{2}{*}{ Waste $^{(2)}$} & \multirow{2}{*}{$\mathrm{pH}$} & \multicolumn{3}{c|}{ Particle Description $\mu \mathrm{m}$} \\
\cline { 3 - 5 } & & Equant & Cubic, Square, Flat & Needle \\
\hline Redox Cladding Waste & $9.4,9.5$ & $2-3$ & $<2$ & - \\
\hline $\begin{array}{l}\text { Redox Cladding Waste \& 3 vol } \\
\% \text { Neutralized Redox Al Waste }\end{array}$ & $9.4,9.5$ & 32 & & $58-62$ \\
\hline $\begin{array}{l}\text { Redox Cladding Waste \& 6 vol } \\
\% \text { Neutralized Redox Al Waste }\end{array}$ & $9.4,9.5$ & - & $<2,13-16,25-28$ & $9-13$ \\
\hline $\begin{array}{l}\text { Redox Cladding Waste with } \\
\text { excess NaOH to meet pH >12 }\end{array}$ & $11.7,11.8$ & $2-3$ & & $2-3$ \\
\hline $\begin{array}{l}\text { Redox Cladding Waste, 3 vol } \\
\% \text { Neutralized Redox Al Waste } \\
\text { \& excess NaOH to meet pH } \\
>12\end{array}$ & $11.8,11.8$ & $3-4$ & & - \\
\hline $\begin{array}{l}\text { Redox Cladding Waste, 6 vol \% } \\
\text { Neutralized Redox Al Waste \& } \\
\text { excess NaOH to meet pH }>12\end{array}$ & $12.0,12.4$ & - & & \\
\hline
\end{tabular}

1) Source of information is Schull and Herting 1986.

2) Composition of cladding waste before neutralization is $0.69 \mathrm{M}\left(\mathrm{NH}_{4}\right)_{2} \mathrm{ZrF}_{6}, 0.77 \mathrm{M} \mathrm{NH}_{4} \mathrm{~F}$, $0.07 \mathrm{M} \mathrm{NH}_{4} \mathrm{NO}_{3}$. Composition of neutralized Redox $\mathrm{Al}$ waste is $0.56 \mathrm{M} \mathrm{NaAl}(\mathrm{OH})_{4}, 0.49 \mathrm{M}$ $\mathrm{NaOH}, 0.46 \mathrm{M} \mathrm{NaNO}_{2}, 3.31 \mathrm{M} \mathrm{NaNO}_{3}$. 
HNF-3130, Rev 0

Table 4-5 Size of Residual Particles in Supernate from Settling Tests of Simulated Direct Neutralized Current Acid Waste ${ }^{(1)}$

\begin{tabular}{|c|c|c|c|}
\hline \multirow{2}{*}{$\begin{array}{c}\text { Settling Time } \\
\mathrm{hr}\end{array}$} & \multicolumn{3}{|c|}{ Particle Size of Supernate $\mu \mathrm{m}$} \\
\cline { 2 - 4 } & Median & Geometric Mean & Arithmetic Mean \\
\hline 0.5 & $1.53-1.89$ & $1.45-1.88$ & $1.49-1.97$ \\
\hline 2.0 & 1.27 & 1.28 & 1.31 \\
\hline 4.0 & 1.33 & 1.32 & 1.34 \\
\hline 9.0 & 1.33 & 1.32 & 1.35 \\
\hline \multicolumn{4}{|c|}{ Aged NCAW $^{(3)}$} \\
\hline 0.2 & $1.50-1.53$ & $1.52-1.57$ & $1.59-1.65$ \\
\hline 2.0 & 1.36 & 1.41 & 1.47 \\
\hline 4.0 & 1.43 & 1.42 & 1.49 \\
\hline $4.0^{(2)}$ & 0.37 & 0.40 & 0.43 \\
\hline
\end{tabular}

1) Source of information is Gerboth 1986. Composition of unneutralized and denitrated current acid waste is $0.95 \mathrm{M} \mathrm{HNO}_{3}, 0.68 \mathrm{M} \mathrm{Al}, 0.14 \mathrm{M} \mathrm{F}, 0.032 \mathrm{~g} / \mathrm{U}$, and $0.0004 \mathrm{~g} / 1 \mathrm{Pu}$. Waste neutralized to $\mathrm{pH}>12$.

2) Elzone analyzer was adjusted to measure smaller size particles.

3) Waste boiled under reflux conditions for 3 weeks at $\mathrm{pH}>12$.

Table 4-6 Particle Sizes Analysis of Simulated Neutralized Current Acid Waste Ripening ${ }^{(1)}$

\begin{tabular}{|c|c|c|c|}
\hline Sample Time Days & Median $\mu \mathrm{m}$ & Geometric Mean $\mu \mathrm{m}$ & Arithmetic Mean $\mu \mathrm{m}$ \\
\hline 0 & 1.46 & 1.45 & 1.51 \\
\hline 5 & 1.43 & 1.43 & 1.49 \\
\hline 12 & 1.53 & 1.55 & 1.62 \\
\hline 15 & 1.53 & 1.54 & 1.61 \\
\hline
\end{tabular}

1) Source of information is Peters and Cleavenger 1985. Waste neutralized to $\mathrm{pH}>12$. 
HNF-3130, Rev 0

4-7 Particle Sizes in Simulated Reverse Neutralized Plutonium Finishing Plant Waste ${ }^{(1)}$

\begin{tabular}{|c|c|c|c|c|}
\hline Chemical & PFP 1 & PFP 4 & PFP 6 & PFP 15 \\
\hline $\mathrm{Al} \mathbf{M}$ & 0.2 & 0.2 & 0.2 & 0.2 \\
\hline $\mathrm{Fe} \mathrm{M}$ & 0 & 0.02 & 0 & 0.02 \\
\hline U M & 0 & 0 & 0.017 & 0.017 \\
\hline $\mathrm{NaF} \mathrm{M}$ & 0.01 & 0.01 & 0.01 & 0.01 \\
\hline $\mathrm{HNO}_{3} \mathrm{M}$ & 2.24 & 2.24 & 2.24 & 2.24 \\
\hline $\mathrm{NaOH} \mathrm{M}$ (final) & 2 & 2 & 2 & 2 \\
\hline $\mathrm{NaNO}_{2} \mathrm{M}^{(2)}$ & 0.05 & 0.05 & 0.05 & 0.05 \\
\hline $\begin{array}{l}\text { Nominal Particle } \\
\text { Size (Geo) um }\end{array}$ & 0.38 & 2.10 & 1.52 & 1.78 \\
\hline $\begin{array}{l}\text { Nominal Particle } \\
\text { Size (Arith) um }\end{array}$ & 0.39 & 2.18 & 1.60 & 1.90 \\
\hline$\%$ Settled Solids & $\begin{array}{l}\text { No } \\
\text { Solids }\end{array}$ & 10.9 & 5.0 & 9.0 \\
\hline $\begin{array}{l}\% \text { Centrifuged } \\
\text { Solids }\end{array}$ & $\begin{array}{l}\text { No } \\
\text { Solids }\end{array}$ & 2.9 & 1.1 & 1.4 \\
\hline
\end{tabular}

1) Source of information is Gallagher 1986.

2 Chemical added after neutralization.

\subsubsection{Neutralization of Uranyl Nitrate Solution}

Laboratory neutralization and settling tests were performed with vigorously mixed uranyl nitrate solutions of $5,10,20,40,70$, and $100 \mathrm{~g} / \mathrm{l}$ to evaluate the settling behavior of the resulting slurries for transfer from Purex to the waste tanks (Ryan 1993). It was concluded that immediately after neutralization, slurries produced from solutions containing $\geq 40 \mathrm{~g} \mathrm{U} / 1$ had a rapid settling fraction that could not be completely poured from the stirring beaker. After 3 to $S$ weeks of slurry aging with agitation, the slurries produced with 5 to $40 \mathrm{~g} \mathrm{U} / 1$ settled very rapidly.

At 70 and $100 \mathrm{~g} \mathrm{U} / 1$, the settling rates are rapid immediately after precipitation. Aging of the slurry on shaker mixer had the opposite effect for these more concentrated slurries and significantly decreased the settling rates. 
HNF-3130, Rev 0

These laboratory test results and observations raise concern that plugging of the transfer line may result from neutralization of solution containing $\geq 40 \mathrm{~g} \mathrm{U} / 1$ particularly if tank stirring and transfer line flow were stopped.

\subsection{Other DOE Site Experience}

Recent coprecipitation results were obtained from Savannah River Site laboratory tests of direct neutralized acid solutions that simulate Purex high activity waste, Purex low activity waste, heavy metal (HM) high activity waste (HAW), and HM low activity waste (LAW) solutions from F-Canyon and H-Canyon operations. The simulated waste contained varying amounts of iron, aluminum, manganese, nickel and uranyl nitrate salts dissolved in $2.0 \mathrm{M}$ nitric acid. Plutonium and uranium were added to the required concentrations. Three additional solutions containing uranium only, plutonium only, and uranium-plutonium were prepared as blanks. Concentrated sodium hydroxide solution was added to portions of the acidic waste and blanks to provide a final liquid phase hydroxide concentration of 1.2 M. This hydroxide concentration is the target concentration for transfer of the high level waste to the waste storage tanks (Hobbs 1995). Table 4-8 lists the waste feed compositions, particle sizes of the precipitate and concentration of plutonium and uranium in the neutralized waste solution and blanks. There was no discernable relationships between time and plutonium and uranium concentrations for any of neutralized waste solution and blanks over a 59 day period.

A portion of the precipitated solids from each waste type was analyzed and included identification of crystalline phase by X-ray diffusion and particle size and morphology by scanning electron microscopic analysis. Plutonium was effectively removed from the simulated Purex and heavy metal waste solutions upon the addition of sodium hydroxide solution by coprecipitation with iron and uranium but not with aluminum. Uranium was observed to be saturated in all alkaline salt solutions except in the heavy metal low activity waste simulant where there was sufficiently high molar ratio of iron to uranium that coprecipitation occurs.

Slurries containing high iron concentration did not settle to as high a solids concentration as the blanks and high aluminum containing slurries. The precipitated solid phases were generally irregularly shaped. Individual crystallites ranged from about 1 to $50 \mu \mathrm{m}$ in diameter except for the uranium blank which ranged from about 5 to $100 \mu \mathrm{m}$ (Hobbs 1995).

Conversation with D. T. Hobbs of Savannah River Technology Center, Westinghouse Savannah River Company indicated there was no other particle size information available on neutralized waste from the production facilities. 
HNF-3130, Rev 0

Table 4-8 Particle Sizes in Simulated Direct Neutralized Savannah River Site Waste ${ }^{(1)}$

\begin{tabular}{|c|c|c|c|c|c|c|c|}
\hline Chemical & $\begin{array}{l}\text { Purex } \\
\text { HAW }\end{array}$ & $\begin{array}{l}\text { Purex } \\
\text { LAW }\end{array}$ & $\begin{array}{l}\text { HM- } \\
\text { HAW }\end{array}$ & $\begin{array}{l}\text { HM- } \\
\text { LAW }\end{array}$ & U Only & Pu Only & $\begin{array}{l}\mathrm{Pu} / \mathrm{U} \\
\text { Only }\end{array}$ \\
\hline Al M & 0.048 & 0 & 1.20 & 0 & 0 & 0 & 0 \\
\hline $\mathrm{Fe} \mathrm{M}$ & 0.11 & 0.53 & 0.02 & 0.15 & 0 & 0 & 0 \\
\hline $\mathrm{Mn} \mathrm{M}$ & 0 & 0.025 & 0 & 0 & 0 & 0 & 0 \\
\hline Ni M & 0.057 & 0 & 0 & 0 & 0 & 0 & 0 \\
\hline $\mathrm{Ug} / \mathrm{l}$ & 9.9 & 0.91 & 0.0029 & 0.0015 & 9.9 & 0 & 9.9 \\
\hline $\mathrm{Pu} \mathrm{g} / \mathrm{l}$ & 0.0017 & 0.0022 & 0.0195 & 0 & 0 & 0.0017 & 0.0017 \\
\hline $\mathrm{HNO}_{3} \mathrm{M}$ & 2.0 & 2.0 & 2.0 & 2.0 & 2.0 & 2.0 & 2.0 \\
\hline $\mathrm{NaOH} \mathrm{M}$ & 1.2 & 1.2 & 1.2 & 1.2 & 1.2 & 1.2 & 1.2 \\
\hline $\mathrm{Pu} \mathrm{mg/l^{(2) }}$ & $\begin{array}{c}6.8 \pm 1.8 \\
\mathrm{E}-04\end{array}$ & $\begin{array}{c}1.1 \pm 0.56 \\
\mathrm{E}-03\end{array}$ & $\begin{array}{c}3.5 \pm 1.4 \\
\mathrm{E}-01\end{array}$ & $\begin{array}{c}\text { Not } \\
\text { Available }\end{array}$ & $\begin{array}{c}\text { Not } \\
\text { Avail. }\end{array}$ & $\begin{array}{c}2.0 \pm 1.6 \\
\text { E-01 }\end{array}$ & $\begin{array}{c}8.4 \pm 4.8 \\
\text { E- } 04\end{array}$ \\
\hline $\mathrm{U} \mathrm{mg} / \mathrm{l}^{(2)}$ & 4. $1 \pm 1.4$ & $4.7 \pm 2.0$ & $2.4 \pm 0.13$ & $0.70 \pm 0.31$ & $4.5 \pm 1.3$ & $0.041 \pm 0.023$ & $6.5 \pm 1.8$ \\
\hline $\begin{array}{l}\text { Aggregate } \\
\text { Particle } \\
\text { Size um }\end{array}$ & None & None & $\begin{array}{c}\text { Not } \\
\text { Available }\end{array}$ & $\begin{array}{c}\text { Not } \\
\text { Available }\end{array}$ & $\begin{array}{l}1,000- \\
10,000\end{array}$ & $10-80$ & $50-300$ \\
\hline $\begin{array}{l}\text { Crystallite } \\
\text { Particle } \\
\text { Size um } \\
\end{array}$ & $\begin{array}{l}1-40 \\
5-50\end{array}$ & $\begin{array}{l}1-40 \\
5-50\end{array}$ & $1-40$ & $\begin{array}{c}\text { Not } \\
\text { Available }\end{array}$ & $5-100$ & $\begin{array}{c}\text { Not } \\
\text { Available }\end{array}$ & $1-20$ \\
\hline $\begin{array}{l}\% \text { Settled } \\
\text { Solids }\end{array}$ & 35 & 84 & 26 & 40 & 16 & $\begin{array}{c}\text { Not } \\
\text { Available }\end{array}$ & 19 \\
\hline
\end{tabular}

1) Source of information is Hobbes 1995

2) Average concentrations in alkaline solution over a 59 day period.

\subsection{Laboratory Tests for K Basin Sludge}

Information was compiled from a recent Russian Institute of Physical Chemistry laboratory study on alkaline treatment of acid dissolver solution for simulated Hanford Site K Basins sludge (PNNL 1998). Sedimentation rates of precipitates formed by alkaline treatment of the simulated dissolver solution showed no regular dependence of the conditions of precipitation (temperature of $40 \& 80^{\circ} \mathrm{C}$, excess $\mathrm{NaOH}$ of $0.01,0.1$ and $1.0 \mathrm{M}$ or direction of neutralization). An intense stirring speed was used to mix the $\mathrm{NaOH}$ and acid solutions. 
HNF-3130, Rev 0

Composition, particle size and precipitate fraction information are listed in Table 4-7. The particle size of the primary crystallites were measure at $<10 \mathrm{~nm}$ using a small angle $X$-ray scattering method. The product precipitate was coagulated for $24 \mathrm{hr}$ at $40^{\circ} \mathrm{C}$, separated from mother solution by 10 minutes centrifugation, and washed 3 times with 5 -fold volumes of water before sampling and analysis.

Based on these studies, the alkaline treatment of the acidic dissolver solution should be performed by precipitation and digestion at $40^{\circ} \mathrm{C}$ with $0.01 \mathrm{M} \mathrm{NaOH}$ excess $(\mathrm{pH} \mathrm{12})$ during direct strike addition of $\mathrm{NaOH}$ to the dissolver solution. These conditions yielded the lowest uranium concentration in the supernate, require the least excess $\mathrm{NaOH}$, and provide the highest apparent partitioning of plutonium. The resulting solutions are non-TRU for both $\mathrm{Pu}$ and $\mathrm{Am}$.

Contact of the product precipitates having no Fe(III) in the solid phase with carbonate-bearing solution can produce TRU level plutonium and americium concentrations in solution. Alkaline solutions containing EDTA also can leach americium to near TRU levels from iron free solids. This contact represent attempts to simulate the reaction that can occur during the tank waste retrieval operations. 
HNF-3130, Rev 0

Table 4-7 Particle Size Distributions of Precipitates from Direct Strike Alkaline Treatment of Simulated Dissolver Solutions at $0.01 \mathrm{M}$ Excess $\mathrm{NaOH} .{ }^{(1)}$

\begin{tabular}{|l|c|c|c|c|c|c|}
\hline \multicolumn{2}{|c|}{ Element Concentration } & \multicolumn{2}{c|}{$\begin{array}{c}\text { Maxima Crystal } \\
\text { Size } \\
\text { nm }\end{array}$} & \multicolumn{2}{c|}{$\%^{2}$ Settled Solids $^{(2)}$} \\
\hline U M & Fe M & Al M & First & Second & Measured & Calculated $^{(3)}$ \\
\hline 0.157 & 0 & 0 & - & $3.4-3.6$ & $45.5,50.3$ & 42.4 \\
\hline 0.141 & 0.068 & 0 & 1.3 & $3.0-3.2$ & $37.0,57.0$ & 47.3 \\
\hline 0.079 & 0.336 & 0 & 1.7 & 2.2 & $70.0,75.0$ & 66.7 \\
\hline 0.016 & 0.603 & 0 & 1.7 & - & $82.0,88.0$ & 85.7 \\
\hline 0.126 & 0 & 0.278 & - & $2.8-3.2$ & $40.5,56.0$ & 52.6 \\
\hline 0.079 & 0 & 0.696 & $3.0-3.1$ & $3.7-4.0$ & $60.5,65.5$ & 68 \\
\hline 0.031 & 0 & 1.11 & $1.8-1.9$ & $2.6-2.8$ & $86.0,86.0$ & 74.4 \\
\hline 0.016 & 0.537 & 0.141 & 1.5 & 1.9 & $85.5,86.0$ & 86.3 \\
\hline 0.016 & 0.068 & 1.11 & 1.9 & - & $92.0,93.0$ & 87.9 \\
\hline 0.025 & 0.224 & 0.463 & 1.9 & - & $67.5,68.5$ & 68 \\
\hline
\end{tabular}

1) Source of information is PNNL 1998

2) Based on initial acid dissolver solution volume before neutralization with $16 \mathrm{M} \mathrm{NaOH}$ ( $\sim 5$ volume\% dilution)

3) Volume fraction of precipitate $=2.7[\mathrm{U}]+1.35[\mathrm{Fe}]+0.67[\mathrm{Al}]$

\subsection{Other World Wide Experience}

Information could not be located for this section to be included at this time. 
HNF-3130, Rev 0

\subsection{DESCRIPTION OF NEUTRALIZATION PROCESS TECHNOLOGIES}

The neutralization systems are continuous stirred tanks, static mixers, and batch tanks

\subsection{Continuous Stirred Tanks}

A schematic of a stirred tank precipitation process is presented in Figure 5-1. This process collects dissolver product solution, washes, and leachate from the main process in a blending tank. The blending tank is operated as batch and sampled as needed. The collected dissolver solution is transferred to the continuous stirred tank for neutralization with $\mathrm{NaOH}$. The stirred tanks have $\mathrm{pH}$ control, agitator for mixing the solution, and possible cooling coils for heat removal. The neutralized solution and precipitate are collected in a holding tank, adjusted for nitrite ion content and sampled. Solution meeting tank farm waste acceptance criteria of Table 3-1 is transferred to the waste tanks.

The continuous stirred tank has the capability to perform either a direct or reverse strike neutralization. The disadvantages of the continuous stirred tank are potential need for multiple mixer chambers to achieve the target $\mathrm{pH}$, the equipment may not have capability to thoroughly mix a gelatinous precipitate with fresh $\mathrm{NaOH}$ solution or move settled solids to the receiver tank, and the equipment may not achieve the level of $\mathrm{pH}$ control in one step flow neutralization process.

\subsection{Static Mixers}

The mixer is shown in Figure 5-2. The system is very similar to the schematic in Figure 5-1 but is mixed by tangential fluid flow. In principle, the unit operates by the introduction of reagent and streams tangentially to a diode chamber. Differences in the inlet velocity promote rapid momentum at the outer perimeter of the diode chamber. The partially mixed stream then migrates towards the central exit port increasing the tangential velocity component by conservation of angular momentum. The narrow streamlines are such that eddy diffusion reduces remaining concentration gradients to acceptable levels prior to exiting the unit. The static unit described above is available from AEA Technologies and has been used at the Enhanced Actinide Remote Plant at Stellafield by British Nuclear Fuel Limited. There are other static mixers available but they contain an internal structure including vanes and other hardware that promote the vorticity.

The static mixers are completely passive and need no mechanical energy input within the unit (e.g. rotating shafts, seals, and impeller blades). The static mixer appears to be capable of either direct or reverse strike neutralization. The disadvantages of the static mixer may be inability to handle gelatinous precipitate, thoroughly mix a viscous alkaline slurry and/or provide the required level of $\mathrm{pH}$ control. 
HNF-3130, Rev 0

Figure 5-1 Continuous Stirred Tank

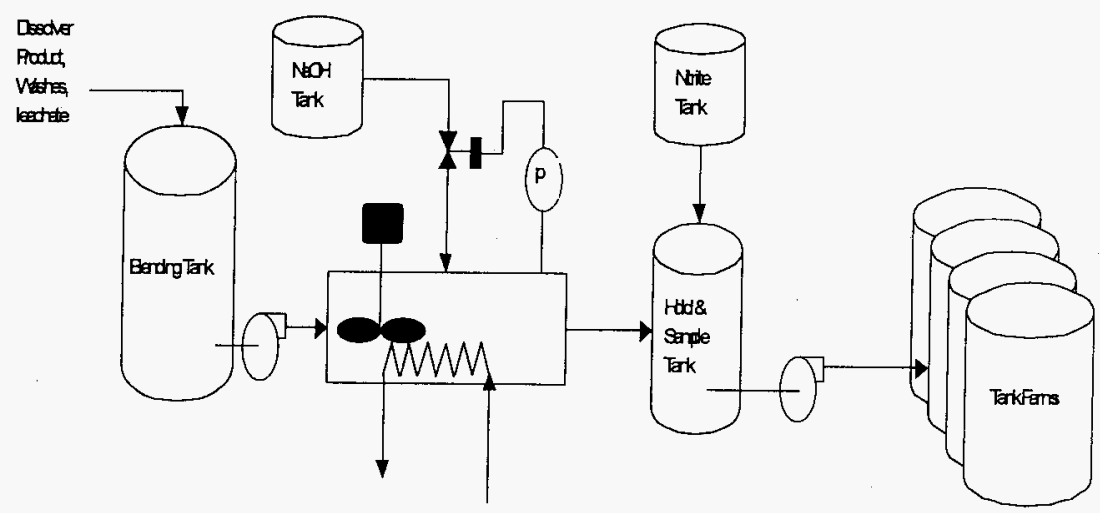


HNF-3130, Rev 0

Figure 5-2A Two port and three port vortex mixers

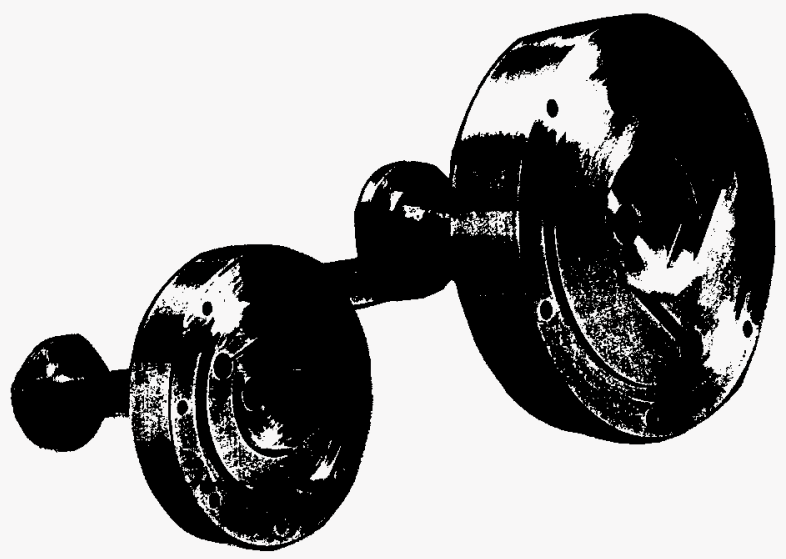

Figure 5-2B A single vortex cell mixing device

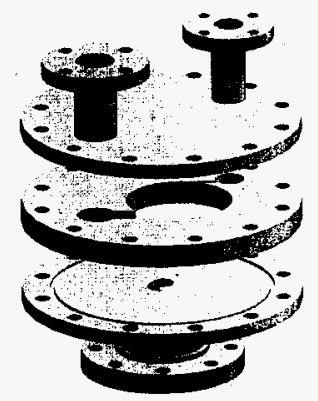


HNF-3130, Rev 0

Figure 5-3 Batch Mixer Tank

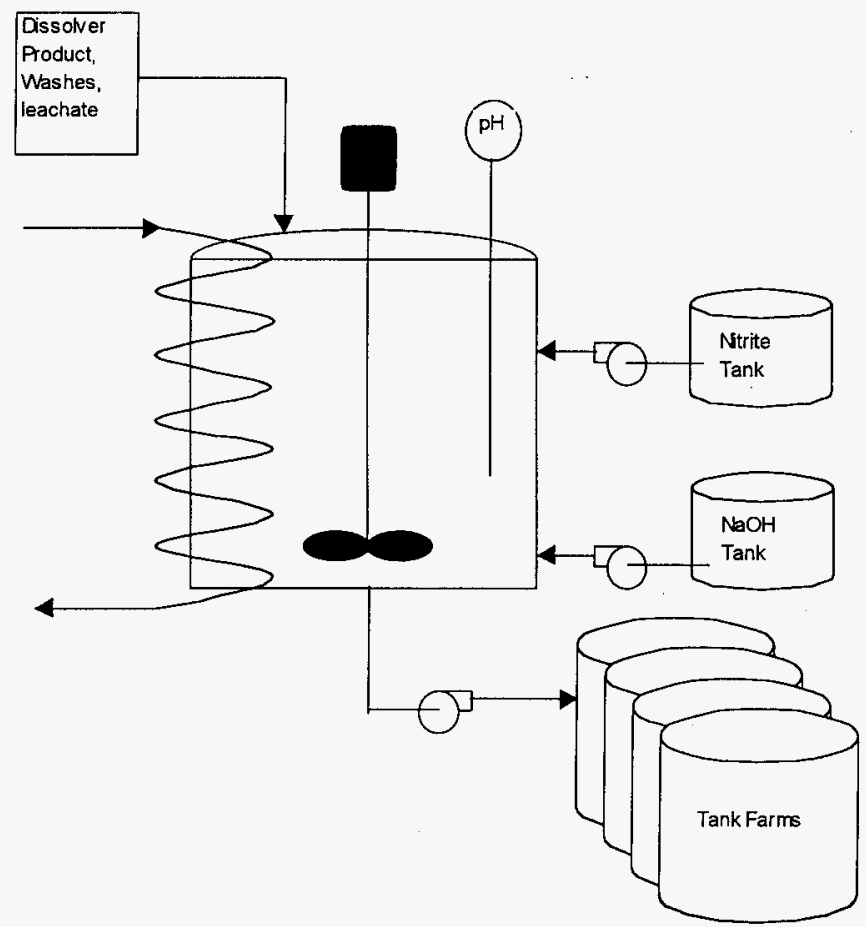


HNF-3130, Rev 0

\subsection{RECOMMENDATIONS}

The following recommendations are provided for the neutralization process and technology.

\subsection{Process}

\subsubsection{Neutralization Method}

The method of neutralization is an important parameter for maintaining operational flexibility and continuity of the proposed sludge pretreatment process. High aluminum waste has been shown to cause operational problems for Redox metal waste and Plutonium Finishing Plant waste. A gelatinous $\mathrm{Al}(\mathrm{OH})_{3}$ precipitate will form at $\mathrm{pH} 4$ to 5 during direct strike neutralization with $\mathrm{NaOH}$ solution. Reverse strike neutralization has been shown to eliminate this solids problem by maintaining high alkalinity conditions in the neutralizer tank. The 1998 PNNL work on neutralization methods of dissolver solution and 1993 Ryan work on neutrailzation of uranyl nitrate used intense mixing of the solutions and do not properly represent dissoiver solution neutralization conditions expected in large equipment systems (e. g. Purex waste neutralization tanks).

Information from the Effluent Treatment Facility at La Hague, France have shown that direct strike neutralization (slow addition of $\mathrm{NaOH}$ to acid) causes a faster precipitation rate of $\mathrm{Pu}$ than $\mathrm{Fe}$. This effect causes a split between $\mathrm{Pu}$ and the neutron absorber iron and may impact maintaining subcriticality. If $\mathrm{NaOH}$ is added and mixed into the acid solution by reverse strike or direct but with special operating conditions that are easily observed in the laboratory, then segregation of $\mathrm{Pu}$ and $\mathrm{Fe}$ would not occur. In large batch systems that typically use slow speed agitators, segregation of $\mathrm{Pu}$ and $\mathrm{Fe}$ may be possible during direct strike neutralization. The neutralization/precipitation process equipment must be designed to coprecipitate iron and plutonium to the maximum extent practical.

Reverse strike neutralization of the nitric acid dissolver solution product into $\mathrm{NaOH}$ solution is recommended for good coprecipitation of $\mathrm{Pu}$ with $\mathrm{Fe}$. Also, reverse strike neutralization eliminates the formation of gelatinous $\mathrm{Al}(\mathrm{OH})_{3}$ at $\mathrm{pH} 4$ to 5 by maintaining high alkaline conditions during neutralization/precipitation.

\subsubsection{Temperature}

The laboratory results from alkaline treatment of sludge dissolver solution showed that a temperature of $40^{\circ} \mathrm{C}$ gave good partitioning of uranium, plutonium and americium and particle size distribution of precipitate (PNNL 1998). Process chemistry information from the Hanford Site Redox plant shows that dissolution of $\mathrm{Al}(\mathrm{OH})_{3}$ is slower or incomplete if the temperature is allowed to go to $>50^{\circ} \mathrm{C}$ during neutralization (GE 1951). Therefore a $40^{\circ} \mathrm{C}$ temperature is recommended for the neutralization process. 
HNF-3130, Rev 0

\subsection{Technology}

The batch mixer tank system is recommended for the initial neutralizer/precipitation system. This equipment system is the simplest of the three equipment systems and has been used at the Hanford Site for neutralization of several waste types for 50 years. Depending on the agitator speed and mixing characteristics of the alkaline slurry, a distributor may be used for addition of the dissolver product solution to the $\mathrm{NaOH}$ in the tank.

The waste neutralization technology is based on laboratory beaker tests that use a magnetic stir bar for intense mixing of the solution and operating facility large tanks that use slow speed agitators and solution distributors. The quality and particle size of the precipitate are dependent on several parameters. These parameters include concentration of constituents in the feed, rate of neutralizing solution addition, and mixing rate of the solutions in the tank.

It is recommended that larger scale neutralization tests be performed to evaluate effect of equipment variables on process chemistry and quality of the precipitate (including the ability to transfer solids to the waste tanks).

\subsection{OPEN ISSUES}

Several open issues have been identified that are important to the success of the K Basin sludge pretreatment. These include:

- Laboratory tests results from neutralization of uranyl nitrate have shown that at a feed concentration $\geq 40 \mathrm{~g} \mathrm{U} / \mathrm{l}$ there was a rapid settling fraction of solids that could not be poured from a just vigorously stirred test beaker. The rapid settling action causes a high risk of accumulation of solids in the neutralizer and transfer line. Numerous rinses would probably be required to remove residual precipitate from the neutralization tank and transfer line to the tank farm.

Action item: 1) Perform further testing and evaluation for optimization of precipitation conditions in order to facilitate handling of the slurry.

2) Perform a reduced scale test at representative conditions to optimize design of the agitator or distributor and behavior of the precipitate including the ability to transfer the precipitate to the waste tanks.

3) Perform a check on the amount of precipitated solids from neutralization and determine if settled solids exceed TWRS limit of $379 \mathrm{~m}^{3}$ (100,000 gal) for tank 241-AW-105. 
HNF-3130, Rev 0

- There was insufficient time to preform a check for applicable information on waste neutralization and particle size from the Oak Ridge National Laboratory and other world wide experience.

Action item: Perform a literature check for available information and establish conversations with cognizant personnel. 
HNF-3130, Rev 0

\subsection{REFERENCES}

AEA 1994, Greenwood, A. N., Final Report on the Utilization of Fluidic Precipitator in the Ferric Floc Treatment of a Low Level Waste and Subsequent Ultra-Filtration Performance, AEA Technology.

Boldt, A. L., 1966, REDOX Chemical Flowsheet - HW No. 9, ISO-335, Isochem Inc, Richland, WA.

Buckingham, J. S., 1998 Telephone conversation July 1998.

Carothers, K. G., K. D. Fowler, J. P. Sloughter, 1997, K Basin Sludge Pretreatment Requirements Summary, HNF-SD-TWR-OCD-001 Rev 0, Lockheed Martin Hanford Company Richland, WA.

Gallagher, S.A., 1986, "Final Report on Plutonium Finishing Plant Parametric Study of Solids Formation", letter 65453-86-075, dated May 20, 1986.

GE 1951, REDOX Technical Mamual, HW-18700 DEL, General Electric Company, Richland, WA.

GE 1955, PUREX Technical Manual, HW-31000 DEL, General Electric Company, Richland, WA.

Gerboth, D. M., 1986, "Results of Neutralized Current Acid Waste Settling/Decant Scoping Tests", letter 65455-86-012, dated February 11, 1986.

Hobbes, D. T., 1995, "Effects of Coprecipitation of Uranium and Plutonium in Alkaline Salt Solutions", letter WSRC-TR-95-0462, dated November 30, 1995, Westinghouse Savannah River Company, Aiken S.C.

ISO-1967, Waste Management Technical Manual, ISO-100 DEL, ISOCHEM, Richland, WA .

Mulkey, C. M., 1997, Data Quality Objective for Tank Farms Waste Capitalization Program, HNF-SD-WM-DQO-001, Rev 2, Lockheed Martin Hanford Company, Richland, WA.

Pearce, K . L., S. C. Klimper, and T. A.Flament, 1998, 105-K Basin Material Design Basis Feed Description for Spent Nuclear Fuel Project Facilities, Volume 2, SLUDGE, HNF-SD-SNF-TI009, Volume 2, Rev 2, Numatec Hanford Corporation, Richland, WA.

Peters, B. B., R. M. Cleavenger, 1985, "Particle Size Analysis of Synthetic Neutralized Current Acid Waste", letter 65453-85-242, dated December 20, 1985, Rockwell Hanford Operations, 
HNF-3130, Rev 0

PNNL 1998, Krot, N. N. et al., Study of the Alkaline Treatment of Acidic Dissolver Solution from the Hanford Site K Basins Sludge for its Disposal to High Level Waste Storage Tanks, Institute of Physical Chemistry, (Russian Academy of Sciences, Moscow Russia) Letter Report 29005-7, Pacific Northwest National Laboratory, Richland, WA, July 1998.

RHO 1980, PUREX Technical Manual, RHO-MA-1 16, Rockwell Hanford Operations, Richland, WA.

Ryan, J. L., 1993, "Neutralization of Uranyl Nitrate Solutions", letter dated January 21, 1993, Pacific Northwest Laboratory, Richland, WA.

Schull, K. E. , D. L. Herting 1986, "Simulated REDOX and PUREX CRW Neutralization”, letter 65453-86-109, dated September 4, 1986 Rockwell Hanford Operation, Richland, WA.

Vail, T. S., P. M. Daling 1997, Feasibility Report on Criticality Issues Associated with Storage of Sludge from Hanford East Basin Floor and Weasel Pit, WHC-SP-1182, Westinghouse Hanford Company, Richland, WA.

Vandercook, R. E., Telephone conversation July 1998.

WHC 1995, Criticality Prevention Specification: Double Shell Tanks, CPS-T-149-00010, Rev G-0, Westinghouse Hanford Company, Richland, WA 
HNF-3130, Rev 0

APPENDIX A

DETAILED COMPOSITION OF THE SLUDGE STREAMS 
COMPOSITION OF THE SOLUTION BEFORE ADJUSTMENT (STREAM \# ST.503)

\begin{tabular}{|c|c|c|c|c|c|c|c|}
\hline & & COMPOSITI & OFADAILYE & TCHFOR & & COMPOSITION & COMPOSITION \\
\hline . & KE1 & KE2 & KW1 & KW2 & KW3 & SOLUTION FROM & TOTAL STREAMS \\
\hline \# OF BATCHES & 146.7 & 24.4 & 11.2 & 10.2 & 22.4 & $\begin{array}{c}\text { SOLID RESIDUES } \\
\text { GROUTINO }\end{array}$ & \\
\hline $\begin{array}{l}\text { Volume } \\
\text { Density } \\
\text { TolaL Mass } \\
\end{array}$ & $\begin{array}{r}4.341 \mathrm{~m}^{3} \\
1.171 \\
5.084 .405 \mathrm{~kg} \\
\end{array}$ & $\begin{array}{r}3.193 \mathrm{~m} 3 \\
1.197 \\
3.822,252 \mathrm{~kg} \\
\end{array}$ & $\begin{array}{r}5.622 \mathrm{~m}^{3} \\
1.149 \\
6.460 .697 \mathrm{~kg} \\
\end{array}$ & $\begin{array}{r}3.255 \mathrm{~ms} \\
1.193 \\
3.883 .487 \mathrm{~kg}\end{array}$ & $\begin{array}{r}2.086 \mathrm{m3}^{1} \\
1.204 \\
3.595 .374 \mathrm{~kg} \\
\end{array}$ & $\begin{array}{r}33.1 \mathrm{~m} \\
1.002 \\
33.161 .9 \mathrm{ko} \\
\end{array}$ & $\begin{array}{r}008.4 \mathrm{m3} \\
1.169 \\
1.061 .926 .0 \mathrm{~kg} \\
\end{array}$ \\
\hline LIQUID & & & & & & & \\
\hline $\begin{array}{l}\text { Volume } \\
\text { Density } \\
\text { Total Mass Liquild + Gaz }\end{array}$ & $\begin{array}{r}4.341 \mathrm{m3} \\
1.171 \\
-5.084 .065 \mathrm{~kg} \\
\end{array}$ & $\begin{array}{r}3.192 \mathrm{m3} \\
1.197 \\
3.822 .177 \mathrm{~kg}\end{array}$ & $\begin{array}{r}5.621 \mathrm{m3} \\
1.149 \\
5,450.076 \mathrm{~kg}\end{array}$ & $\begin{array}{r}3.255 \mathrm{m3} \\
1.193 \\
3,883.398 \mathrm{~kg}\end{array}$ & $\begin{array}{r}2.985 \mathrm{m3} \\
1.204 \\
3.595 .342 \mathrm{~kg}\end{array}$ & $\begin{array}{r}33.1 \mathrm{m3} \\
1.002 \\
33.161 .9 \mathrm{~kg}\end{array}$ & $\begin{array}{r}808.4 \mathrm{m3} \\
1.170 \\
1.061 .856 .2 \mathrm{~kg} \\
\end{array}$ \\
\hline $\mathrm{H} 2 \mathrm{O}$ & $3,644,081 \mathrm{~kg}$ & $2,573.333 \mathrm{~kg}$ & $4,866.661 \mathrm{~kg}$ & $2,642,356 \mathrm{~kg}$ & $2.378 .651 \mathrm{~kg}$ & $33.130 .0 \mathrm{~kg}$ & $763,152.5 \mathrm{~kg}$ \\
\hline $\begin{array}{l}\mathrm{HNO3} \\
\mathrm{H} 2 \mathrm{C} 2 \mathrm{O} 4\end{array}$ & $\begin{array}{r}1.193 .699 \mathrm{~kg} \\
1.498 \mathrm{~kg}\end{array}$ & $\begin{array}{r}993.604 \mathrm{~kg} \\
0.250 \mathrm{~kg}\end{array}$ & $\begin{array}{r}1,452.018 \mathrm{~kg} \\
0.050 \mathrm{~kg}\end{array}$ & $\begin{array}{r}1,000.957 \mathrm{~kg} \\
0.459 \mathrm{~kg}\end{array}$ & $\begin{array}{r}953.518 \mathrm{~kg} \\
0.050 \mathrm{~kg}\end{array}$ & $\begin{array}{r}31.2 \mathrm{~kg} \\
0.2 \mathrm{~kg}\end{array}$ & $\begin{array}{r}246.553 .8 \mathrm{~kg} \\
231.6 \mathrm{~kg}\end{array}$ \\
\hline $\begin{array}{l}\mathrm{HF} \\
\mathrm{NaOH}\end{array}$ & $4.395 \mathrm{~kg}$ & $1.049 \mathrm{~kg}$ & $9.788 \mathrm{~kg}$ & $1.149 \mathrm{~kg}$ & $0.520 \mathrm{~kg}$ & $0.5 \mathrm{~kg}$ & $801.0 \mathrm{~kg}$ \\
\hline $\begin{array}{l}\text { Al(NO3)3 } \\
\text { AlF3 }\end{array}$ & $51.740 \mathrm{~kg}$ & $37.692 \mathrm{~kg}$ & $34.843 \mathrm{~kg}$ & & $48.879 \mathrm{~kg}$ & $0.0 \mathrm{~kg}$ & $9.966 .6 \mathrm{~kg}$ \\
\hline $\begin{array}{l}\mathrm{Fe}(\mathrm{NO} 3) 3 \\
\mathrm{CaO}\end{array}$ & $\begin{array}{r}146.730 \mathrm{~kg} \\
1.742 \mathrm{~kg}\end{array}$ & $\begin{array}{r}23.836 \mathrm{~kg} \\
0.118 \mathrm{~kg}\end{array}$ & $\begin{array}{r}78.238 \mathrm{~kg} \\
1.551 \mathrm{~kg}\end{array}$ & & $\begin{array}{r}40.426 \mathrm{~kg} \\
0.074 \mathrm{~kg}\end{array}$ & $\begin{array}{l}0.1 \mathrm{~kg} \\
0.0 \mathrm{~kg}\end{array}$ & $\begin{array}{r}23,804.2 \mathrm{~kg} \\
276.3 \mathrm{~kg}\end{array}$ \\
\hline $\begin{array}{l}\text { NaNO2 } \\
\text { NaNO3 }\end{array}$ & & & & & & & \\
\hline Miscellaneous & $10.575 \mathrm{~kg}$ & $1.346 \mathrm{~kg}$ & $3.988 \mathrm{~kg}$ & $0.812 \mathrm{~kg}$ & $10.294 \mathrm{~kg}$ & $0.0 \mathrm{~kg}$ & $1,861.9 \mathrm{~kg}$ \\
\hline UO2(NO3)? & $29.607 \mathrm{~kg}$ & $190.949 \mathrm{~kg}$ & $12.939 \mathrm{~kg}$ & $237.664 \mathrm{~kg}$ & $162.931 \mathrm{~kg}$ & $0.0 \mathrm{~kg}$ & $15218.2 \mathrm{~kg}$ \\
\hline$P u$ & $3.004 \mathrm{Ci}$ & $20.380 \mathrm{Ci}$ & $1.850 \mathrm{Ci}$ & $24.371 \mathrm{Ci}$ & $23.248 \mathrm{Ci}$ & $0.0 \mathrm{Ci}$ & $1.727 .8 \mathrm{Ci}$ \\
\hline$A m$ & $3.885 \mathrm{Cl}$ & $23.658 \mathrm{Ci}$ & $1.754 \mathrm{Ci}$ & $19.869 \mathrm{Ci}$ & $18.370 \mathrm{Ci}$ & $0.0 \mathrm{Ci}$ & $1.780 .3 \mathrm{Ci}$ \\
\hline $\mathrm{Cs}$ & $49010 \mathrm{Cl}$ & $219.530 \mathrm{Ci}$ & $15.423 \mathrm{Ci}$ & $779.393 \mathrm{Ci}$ & $261.506 \mathrm{Ci}$ & $0.1 \mathrm{Ci}$ & $26,525.6 \mathrm{Ci}$ \\
\hline sr & $45.491 \mathrm{Ci}$ & $246.546 \mathrm{Ci}$ & $10.016 \mathrm{Ci}$ & $607.904 \mathrm{Ci}$ & $361.516 \mathrm{Ci}$ & $0.0 \mathrm{Ci}$ & $27,100.6 \mathrm{Ci}$ \\
\hline $\mathrm{PCB}$ & 0,0020 & $0002 a$ & & & 0,0020 & 00000 & $0344 a$ \\
\hline SOLIDS + RESINS & & & & & & & \\
\hline Volume & $0.000 \mathrm{~m} 3$ & $0.000 \mathrm{~m}^{3}$ & $0.000 \mathrm{~m} 3$ & $0.000 \mathrm{~ms}$ & $0.000 \mathrm{~m} 3$ & & $0.0 \mathrm{~m} 3$ \\
\hline Density & 2.022 & 3.582 & 2.211 & 4.737 & 2.326 & & 2.136 \\
\hline Total Mass Solids \pm Resins & $0.338 \mathrm{~kg}$ & $0.074 \mathrm{~kg}$ & $0.621 \mathrm{~kg}$ & $0.090 \mathrm{~kg}$ & $0.033 \mathrm{~kg}$ & & $59.8 \mathrm{~kg}$ \\
\hline Wers sollds & $0.01 \mathrm{wr} \%$ & $0.00 \mathrm{wt} \%$ & $0.01 \mathrm{wt} \%$ & $0.00 \mathrm{wr}$ & $0.00 \mathrm{wr} \%$ & $0.00 w t \%$ & $0.01 w \%$ \\
\hline $\mathrm{Al}(\mathrm{NO} 3)_{3} 3$ & & & & & & & \\
\hline $\mathrm{Al}(\mathrm{OH}) 3$ & $0.000 \mathrm{~kg}$ & $0.001 \mathrm{~kg}$ & & & $0.001 \mathrm{~kg}$ & & $0.1 \mathrm{~kg}$ \\
\hline $\mathrm{Al} 2 \mathrm{O} 3$ & $0.003 \mathrm{~kg}$ & & $0.003 \mathrm{~kg}$ & & & & $0.5 \mathrm{~kg}$ \\
\hline $\mathrm{Fe}(\mathrm{NO}) 3$ & & & & & & & \\
\hline $\mathrm{FeOOH}$ & $0.003 \mathrm{~kg}$ & $0.004 \mathrm{~kg}$ & $0.002 \mathrm{~kg}$ & & $0.001 \mathrm{~kg}$ & & $0.5 \mathrm{~kg}$ \\
\hline c & $0.001 \mathrm{~kg}$ & $0.001 \mathrm{~kg}$ & $0.000 \mathrm{~kg}$ & & $0,001 \mathrm{~kg}$ & & $0.2 \mathrm{~kg}$ \\
\hline $\begin{array}{l}\mathrm{CaO} \\
\mathrm{Na} 2 \mathrm{C}_{2} \mathrm{O} 4\end{array}$ & $0.001 \mathrm{~kg}$ & $0.000 \mathrm{~kg}$ & $0.00: \mathrm{kg}$ & & $0.000 \mathrm{~kg}$ & & $0.2 \mathrm{~kg}$ \\
\hline $\mathrm{CO} 2$ & & & & & & & \\
\hline $\begin{array}{l}\mathrm{H} 2 \mathrm{O} \\
\mathrm{SiO} 2\end{array}$ & $0.253 \mathrm{~kg}$ & $0.039 \mathrm{~kg}$ & $0.615 \mathrm{~kg}$ & & $0.029 \mathrm{~kg}$ & & $454 \mathrm{~kg}$ \\
\hline Grout & 0 cosd hy & $0.009 \mathrm{~kg}$ & $0.010 \mathrm{~kg}$ & & $0.0<5 \mathrm{ng}$ & & $40.4 \mathrm{~kg}$ \\
\hline Miscellaneous & $0.001 \mathrm{~kg}$ & $0.000 \mathrm{~kg}$ & $0.000 \mathrm{~kg}$ & $0.000 \mathrm{~kg}$ & $0.001 \mathrm{~kg}$ & & $0.1 \mathrm{~kg}$ \\
\hline Zircaloy & & $0.024 \mathrm{~kg}$ & & $0.058 \mathrm{~kg}$ & & & $1.2 \mathrm{~kg}$ \\
\hline Graloil & & & & $0.031 \mathrm{~kg}$ & & & $0.3 \mathrm{~kg}$ \\
\hline $\mathrm{HNO3}$ & & & & & & & \\
\hline$\frac{\mathrm{H}_{2} \mathrm{C}_{2} \mathrm{O} 4}{\mathrm{Na} 2 \mathrm{U}^{2} \mathrm{O}}$ & & & & & & & \\
\hline $\mathrm{Na} 20207$ & & & & & & & \\
\hline U & $0.000 \mathrm{~kg}$ & $0.000 \mathrm{~kg}$ & $0.000 \mathrm{~kg}$ & $0.001 \mathrm{~kg}$ & $0.000 \mathrm{~kg}$ & & $0.0 \mathrm{~kg}$ \\
\hline U 307 & $0.000 \mathrm{~kg}$ & $0.000 \mathrm{~kg}$ & $0.000 \mathrm{~kg}$ & & $0.000 \mathrm{~kg}$ & & $0.0 \mathrm{~kg}$ \\
\hline $\mathrm{UH} 3$ & $0.000 \mathrm{~kg}$ & $0.000 \mathrm{~kg}$ & & & $0.000 \mathrm{~kg}$ & & $0.0 \mathrm{~kg}$ \\
\hline UO2 & $0.000 \mathrm{~kg}$ & $0.000 \mathrm{~kg}$ & $0.000 \mathrm{~kg}$ & & $0.000 \mathrm{~kg}$ & & $0.0 \mathrm{~kg}$ \\
\hline$\frac{\mathrm{UO}}{\mathrm{PU}}$ & $\frac{0.000 \mathrm{~kg}}{0.000 \mathrm{cl}}$ & $0.000 \mathrm{Ci}$ & & & $\frac{0.000 \mathrm{~kg}}{0.000 \mathrm{Ci}}$ & & $0.0 \mathrm{~kg}$ \\
\hline $\begin{array}{l}P U \\
A m\end{array}$ & $0.000 \mathrm{Cj}$ & $0.000 \mathrm{Ci}$ & $0.000 \mathrm{Ci}$ & $0.000 \mathrm{Ci}$ & $\begin{array}{l}0.000 \mathrm{Ci} \\
0.000 \mathrm{Ci}\end{array}$ & & $\begin{array}{l}0.0 \mathrm{Ci} \\
0.0 \mathrm{Ci}\end{array}$ \\
\hline Cs & $0.001 \mathrm{Cl}$ & $0.005 \mathrm{Ci}$ & $0.000 \mathrm{Ci}$ & $0.017 \mathrm{Ci}$ & $0.006 \mathrm{Ci}$ & & $0.6 \mathrm{Ci}$ \\
\hline Sr & $0.000 \mathrm{Ci}$ & $0.001 \mathrm{Ci}$ & $0.000 \mathrm{Ci}$ & $0.002 \mathrm{Ci}$ & $0.001 \mathrm{Cl}$ & & $0.1 \mathrm{Ci}$ \\
\hline$P C g$ & 0.0619 & $0.000_{8}$ & & & $0.001 \mathrm{~g}$ & & $8.937 \mathrm{~g}$ \\
\hline RESINS & & & & & & & \\
\hline Zeolite & $0.029 \mathrm{~kg}$ & & & & & & $4.2 \mathrm{~kg}$ \\
\hline OIER & $0.047 \mathrm{~kg}$ & $0,008 \mathrm{~kg}$ & & & & & $7.1 \mathrm{~kg}$ \\
\hline$P u$ & $0.000 \mathrm{Ci}$ & $0.000 \mathrm{Ci}$ & & & & & $0.019 \mathrm{Cl}$ \\
\hline$A m$ & $0000 \mathrm{Ci}$ & $0.000 \mathrm{Ci}$ & $0.000 \mathrm{Ci}$ & & & & $0.003 \mathrm{Ci}$ \\
\hline Cs & $0,003 \mathrm{Cil}$ & $0001 \mathrm{ci}$ & & & & & $0,452 \mathrm{Ci}$ \\
\hline TOTAL ACTIVITIES & & & & & & & \\
\hline Total U & $17.884 \mathrm{~kg}$ & $115.345 \mathrm{~kg}$ & 7.816 kg & $143.564 \mathrm{~kg}$ & $98.420 \mathrm{~kg}$ & $0.0 \mathrm{~kg}$ & $9.192 .7 \mathrm{~kg}$ \\
\hline Total Pu & $3.004 \mathrm{Ci}$ & $20.380 \mathrm{Ci}$ & $1850 \mathrm{Ci}$ & $24.371 \mathrm{Ci}$ & $23.248 \mathrm{Cl}$ & $0.0 \mathrm{Ci}$ & $1,727.9 \mathrm{Ci}$ \\
\hline Total Am & $3.885 \mathrm{Ci}$ & $23.658 \mathrm{Ci}$ & $1.754 \mathrm{Ci}$ & $19.870 \mathrm{Ci}$ & $18.370 \mathrm{Ci}$ & $0.0 \mathrm{Ci}$ & $1,780,3 \mathrm{Ci}$ \\
\hline TRU & $6.889 \mathrm{Ci}$ & $44.038 \mathrm{Ci}$ & $3.603 \mathrm{Ci}$ & $44.241 \mathrm{Cl}$ & $41.619 \mathrm{cl}$ & $0.0 \mathrm{Cl}$ & $3,508.2 \mathrm{Cg}$ \\
\hline Total Cs & $49.014 \mathrm{Ci}$ & $219.535 \mathrm{Ci}$ & $15.423 \mathrm{Ci}$ & $779.410 \mathrm{Ci}$ & $261.512 \mathrm{Ci}$ & $0.1 \mathrm{Ci}$ & $26.526 .6 \mathrm{Ci}$ \\
\hline Totalsr & $45.491 \mathrm{Ci}$ & $246.547 \mathrm{Ci}$ & $10.016 \mathrm{Ci}$ & $607.907 \mathrm{Ci}$ & $361.517 \mathrm{Ci}$ & $0.0 \mathrm{Ci}$ & $27,1007 \mathrm{Ci}$ \\
\hline Beta Gamma & $94.504 \mathrm{Cl}$ & $466.081 \mathrm{Ci}$ & $25,439 \mathrm{Cl}$ & $1387317 \mathrm{Cl}$ & $623.029 \mathrm{cl}$ & $0.7 \mathrm{Ci}$ & $53.627,3 \mathrm{ci}$ \\
\hline CONCENTRATION & & & & & & & \\
\hline PCB in liquid & $0.35 \mathrm{ppb}$ & $0.48 \mathrm{ppb}$ & & & $0.51 \mathrm{ppb}$ & $0.00 \mathrm{ppb}$ & $0.32 \mathrm{ppb}$ \\
\hline PCB in solids & $180.214 \mathrm{ppm}$ & $1.459 \mathrm{ppm}$ & & & $33.759 \mathrm{ppm}$ & & $362 \mathrm{ppm}$ \\
\hline Solids & $0.08 \mathrm{~g} /$ & $0.02 \mathrm{~g} / 1$ & $0.11 \mathrm{~g} / \mathrm{I}$ & $0.03 \mathrm{~g} / 1$ & $0.01 \mathrm{~g}$ & & $0.07 \mathrm{~g} /$ \\
\hline U. & $0.004 \mathrm{~g} / \mathrm{cm} 3$ & $0,036 \mathrm{~g} / \mathrm{cm} 3$ & $0,001 \mathrm{~g} / \mathrm{cm} 3$ & $0.044 \mathrm{~g} / \mathrm{cm} 3$ & $0.033 \mathrm{o} / \mathrm{cm} 3$ & 0.000 olcm 3 & $0.0100 / \mathrm{cm}^{3}$ \\
\hline Putotal & $0.692 \mathrm{Cl} / \mathrm{m} 3$ & $6.384 \mathrm{Cl} / \mathrm{m} 3$ & $0.329 \mathrm{Cl} / \mathrm{m}^{3}$ & $7.487 \mathrm{Ci} / \mathrm{m}^{3}$ & $7.787 \mathrm{ci} / \mathrm{m}^{3}$ & $0.000 \mathrm{cl} / \mathrm{m}^{3}$ & $1.902 \mathrm{ct} / \mathrm{m} 3$ \\
\hline $238 \mathrm{Pu}$ & $0.138 \mathrm{Ci} / \mathrm{m} 3$ & $1.277 \mathrm{Ci} / \mathrm{m} 3$ & $0,066 \mathrm{Ci} / \mathrm{m} 3$ & 1. $497 \mathrm{Ci} / \mathrm{m} 3$ & $1.557 \mathrm{Ci} / \mathrm{m} 3$ & $0.000 \mathrm{C} / \mathrm{m} 3$ & $0.380 \mathrm{Ci} / \mathrm{m} 3$ \\
\hline $239 \mathrm{Pu}$ & $0.277 \mathrm{cl} / \mathrm{m} 3$ & $2.554 \mathrm{Ci} / \mathrm{m} 3$ & $0.132 \mathrm{cu} / \mathrm{m} 3$ & $2.995 \mathrm{Cim} 3$ & $3.115 \mathrm{Cv} / \mathrm{m}^{3}$ & $0.000 \mathrm{cl} / \mathrm{m} 3$ & 0.761 Cirm3 \\
\hline $240 \mathrm{Pu}$ & $0.277 \mathrm{C} / \mathrm{m} 3$ & $2.554 \mathrm{Cv} / \mathrm{m} 3$ & $0.132 \mathrm{Ci} / \mathrm{m} 3$ & $2995 \mathrm{Cv} / \mathrm{m}^{3}$ & $3.115 \mathrm{Cv} / \mathrm{m}^{3}$ & $0.000 \mathrm{CV} / \mathrm{m}^{3}$ & $0.761 \mathrm{Ci} / \mathrm{m} 3$ \\
\hline $\mathrm{Am}$ & $0.895 \mathrm{cl} / \mathrm{m} 3$ & $7.410 \mathrm{cl} / \mathrm{m} 3$ & $0.312 \mathrm{Cvm} 3$ & $6.104 \mathrm{Cum3}$ & $6.153 \mathrm{cV} / \mathrm{m}^{3}$ & $0.000 \mathrm{Ci} / \mathrm{m} 3$ & $1.960 \mathrm{Cu} / \mathrm{m}^{3}$ \\
\hline TRU & $1.587 \mathrm{Ct} / \mathrm{m} 3$ & $13794 \mathrm{Cim} 3$ & $0.641 \mathrm{cum} 3$ & $13.590 \mathrm{Ci} / \mathrm{m} 3$ & $13.940 \mathrm{CV} / \mathrm{m} 3$ & $0.000 \mathrm{C} / \mathrm{m} 3$. & $3.862 \mathrm{Ci} / \mathrm{m}$ \\
\hline TRU & $\begin{array}{r}1355 \mathrm{nCi} / \mathrm{g} \\
21.769 \mathrm{Ci} / \mathrm{m} 3\end{array}$ & $\begin{array}{r}11522 \mathrm{nCi} / \mathrm{g} \\
145.992 \mathrm{Cl} / \mathrm{m}^{3}\end{array}$ & $\begin{array}{r}558 \mathrm{nCl} / \mathrm{g} \\
4.525 \mathrm{cl} / \mathrm{m}^{3}\end{array}$ & $\begin{array}{r}11392 \mathrm{nCHg} \\
426.169 \mathrm{Cl} / \mathrm{m}^{3}\end{array}$ & $\begin{array}{r}11576 \mathrm{nCi} / \mathrm{g} \\
208,680 \mathrm{C} / \mathrm{m} 3\end{array}$ & $\begin{array}{r}0 \mathrm{nCl} / \mathrm{g} \\
0.005 \mathrm{cl} / \mathrm{m} 3\end{array}$ & $\begin{array}{r}3.304 \mathrm{nCi} / \mathrm{g} \\
59.033 \mathrm{Ct} / \mathrm{m} 3\end{array}$ \\
\hline
\end{tabular}


COMPOSITION OF THE SOLUTION BEFORE NEUTRALIZATION (STREAM * ST-601)

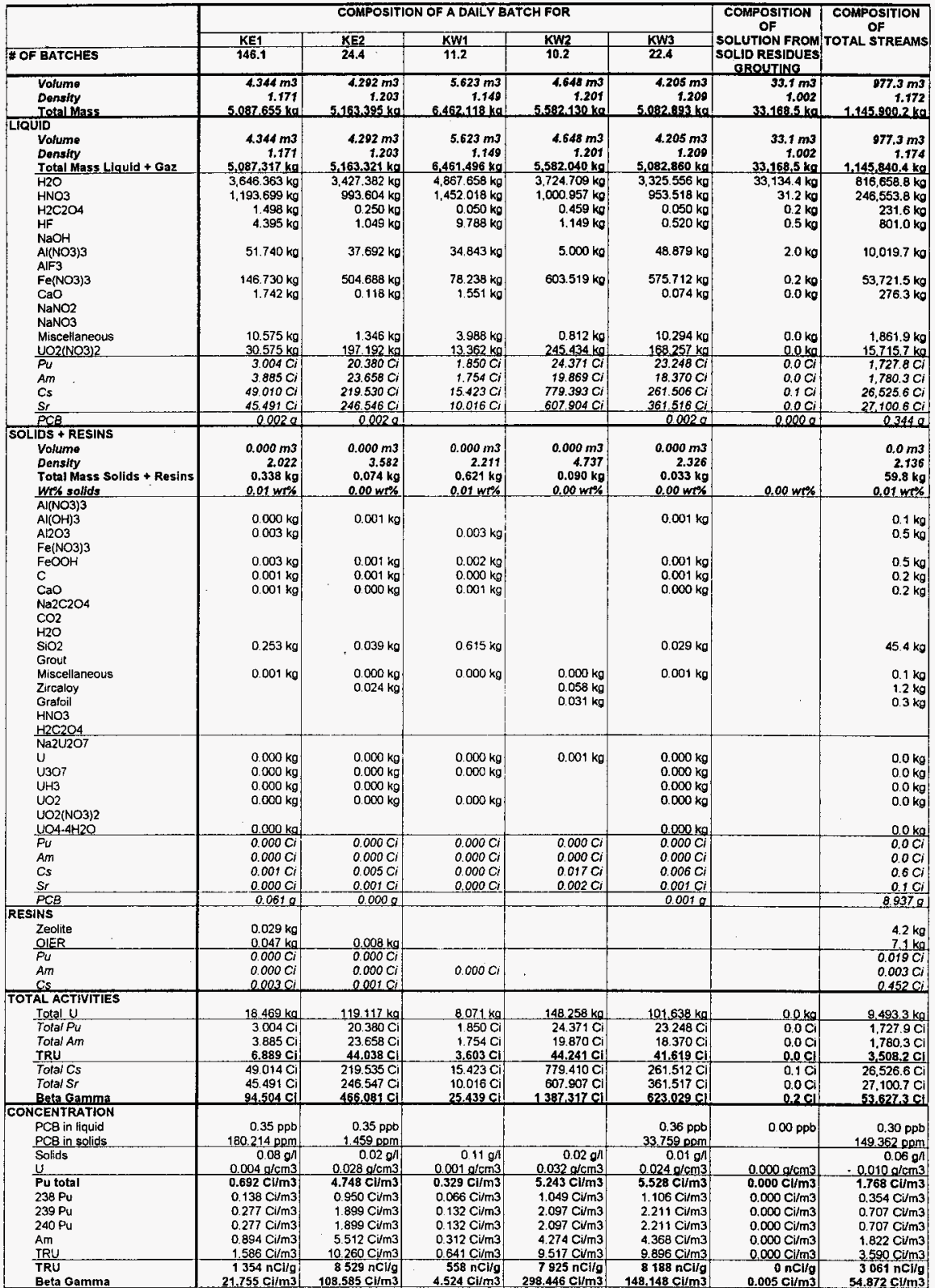


COMPOSITION OF THE SLURRY AFTER NEUTRALIZATION AND WATER ADJUSTMENT (STREAM \# ST-604)

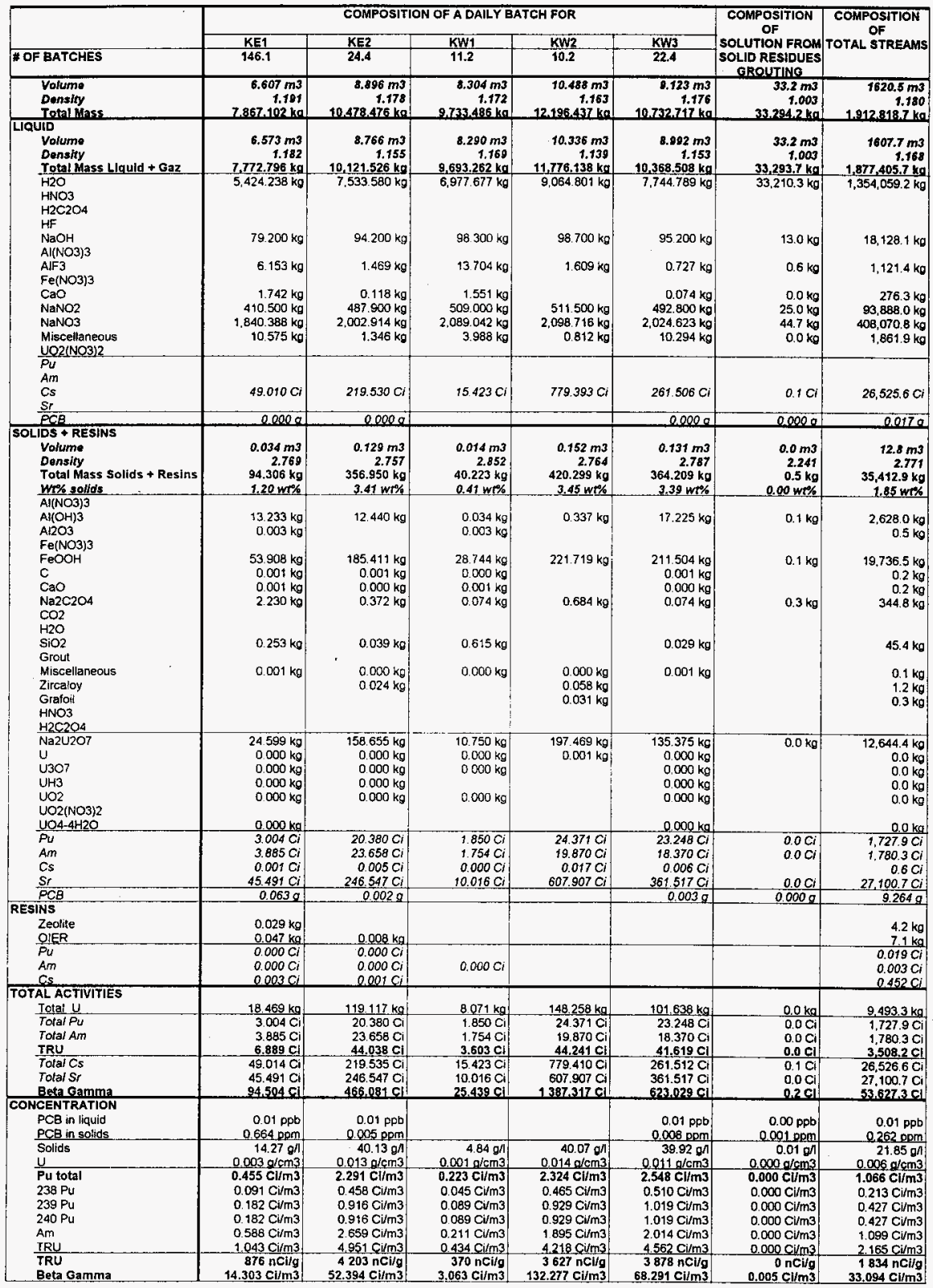




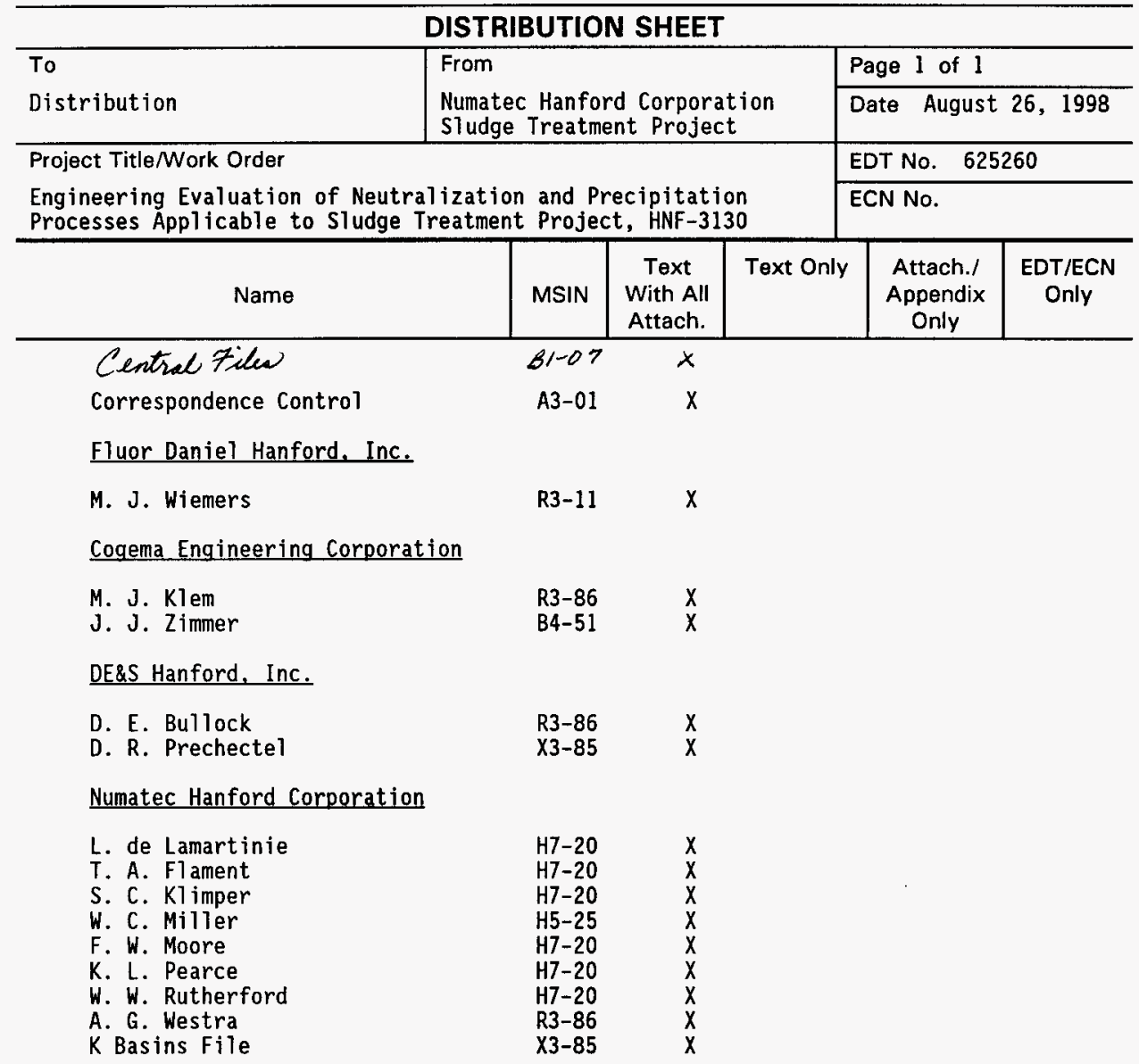

